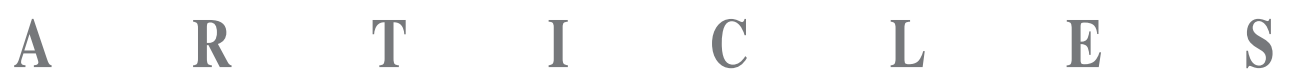

\title{
Regulating Unfair Trading Practices in the EU Agri-food Supply Chain: a Case of Counterproductive Regulation?
}

\author{
by
}

Victoria Daskalova*

\section{CONTENTS}

I. Introduction

II. The question of UTPs in the agri-food supply chain: a question for competition law or for other regulation?

III. The rise of stricter unilateral conduct rules in the EU: mapping national approaches

IV. The counterproductive regulation typology

V. Displacement: problem moving, but not disappearing

1. Forum shopping and trade diversion: limits to unilateral solutions in an integrated market

2. Policy problem shifted to private law

3. UTPs and the Common Agricultural Policy

VI. Escalation: does more regulation on unfairness lead to more unfair outcomes?

VII. Perverse incentives: who benefits from the CAP?

VIII. Over-deterrence: how many pieces of legislation does it take to tackle UTPs?

* Victoria Daskalova LL.M., LL.M., PhD. The author is an Assistant Professor in Law, Governance \& Technology at the University of Twente, the Netherlands; e-mail: v.i.daskalova@ utwente.nl; ORCID: 0000-0003-2426-1339. The usual disclaimer applies. The paper was substantially developed during and after a research stay in Melbourne Law School in 2017. The author thanks Caron Beaton-Wells, Jo Paul and the other members of the Supermarket Power Project at Melbourne Law School for the inspiring research environment and helpful comparative insights, and the University of Twente Incentive Fund for the financial support. I would like to thank Wolf Sauter for comments on an earlier draft of this paper.

Article received: 7 April 2020, accepted: 27 July 2020. 
IX. Re-examining enforcement priorities

$\mathrm{X}$. Broader implications: the future of competition law, smart regulation, and the internal market

1. The role of other laws

2. The integration imperative

XI. Conclusion

\section{Abstract}

Unfair trading practices (UTPs) imposed by parties with superior power in the context of a vertical relationship are an issue at the periphery of competition law, private law, and, sometimes, sectoral regulation. For a long time, the mainstream competition law approach has been to relegate such issues to other areas of law and regulation. In the EU, where complaints about the prevalence of such practices in the agricultural and food supply chain have been voiced for decades, the approach of the European Commission has been to pursue a strict separation between competition issues and fair-trading issues. This article questions the reasonableness of such a strict division of labour. Taking the sum of various initiatives undertaken to regulate UTPs in the agri-food supply chain as a case study, it argues that the effect of limiting competition law enforcement on this issue has been counterproductive. The article firstly explains the background of the problem and the issue of UTPs in the agri-food supply chain. Secondly, it maps the various legislative developments which have taken place at the EU Member State level. Thirdly, by referring to Grabosky's (1995) regulatory studies typology of counterproductive regulation, the article focuses attention on some of the perverse side effects which arise when regulation of power imbalances and UTPs occurs at the national level in the context of an integrated market like the EU. In light of the analysis, it expresses doubt that these pitfalls will be fully corrected by Directive 2019/633 on UTPs in the food supply chain. The conclusion is that national legislative developments have not been able to make up for the lack of supra-national enforcement of EU competition law on this issue and have possibly even exacerbated the problem at hand. The article concludes that supranational competition law enforcement can play a key role in addressing the fundamental problems underlying business-to-business unfair trading practices. It argues that this role cannot be played by other instruments in the context of an integrated market with multi-level governance. This article shows that while competition law may not be capable of solving all the problems with UTPs, it remains indispensable in safeguarding the proper functioning of the internal market as well as the interests of consumers and taxpayers.

\section{Résumé}

Les pratiques commerciales déloyales (PCD) imposées par des parties détenant un pouvoir supérieur dans le cadre d'une relation verticale sont une problématique qui se situe à la marge du droit de la concurrence, du droit privé 
et, quelques fois, de la réglementation sectorielle. Pendant longtemps, l'approche générale du droit de la concurrence a consisté à déléguer ces problématiques à d'autres domaines du droit et de la réglementation. Dans l'UE, l'approche de la Commission européenne a été de poursuivre une séparation stricte entre les questions de concurrence et les questions concernant les PCD. Cet article s'interroge sur le caractère raisonnable d'une division du travail si rigoureuse. En prenant comme cas d'étude la combinaison de diverses initiatives adoptées pour réglementer les PCD dans la chaîne d'approvisionnement agroalimentaire, il soutient que l'effet de la limitation de l'application du droit de la concurrence sur cette question a été contre-productif.

Larticle explique tout d'abord le contexte du problème et la question des PTU dans la chaîne d'approvisionnement agroalimentaire. Ensuite, il dresse la fiche des différentes évolutions législatives qui ont eu lieu au niveau des États membres de l'UE. Enfin, en se référant à la méthodologie des études réglementaires de Grabosky (1995) sur la réglementation contre-productive, l'article souligne certains des effets secondaires négatifs qui surviennent lorsque la réglementation des déséquilibres de pouvoir et des PCD se fait au niveau national dans le contexte d'un marché intérieur comme l'UE. À la lumière de l'analyse, il exprime des doutes sur le fait que ces risques seront entièrement corrigés par la directive 2019/633 sur les PCD dans la chaîne d'approvisionnement alimentaire. La conclusion est que les développements législatifs nationaux n'ont pas été capables de compenser le manque d'application supranationale du droit européen de la concurrence sur la question et ont même peut être exacerbé le problème en question. Larticle conclut que l'application supranationale du droit de la concurrence peut jouer un rôle clé dans la résolution des problèmes fondamentaux qui sous-tendent les pratiques commerciales déloyales entre entreprises. Il affirme que ce rôle ne peut être joué par d'autres instruments dans le contexte d'un marché intérieur avec une gouvernance à plusieurs niveaux. Cet article montre que si le droit de la concurrence n'est peut-être pas capable de résoudre tous les problèmes posés par les PCD, il reste indispensable pour préserver le bon fonctionnement du marché intérieur ainsi que les intérêts des consommateurs.

Key words: buyer power; business-to-business; competition law; food supply chain; superior bargaining power; unfair trading practices.

JEL: K12, K21, K23, K40 


\section{Introduction}

Directive $2019 / 633^{1}$ is arguably one of the first pieces of EU legislation specifically dedicated to the issue of business-to-business unfair trading practices (hereinafter, UTPs). Proposed in April 2018, ${ }^{2}$ the Directive, which targets specifically UTPs in the agricultural and food supply chain ${ }^{3}$ was adopted with amendments a year later. The relatively quick process from proposal to adoption, however, should not mislead observers: the issue of business-to-business UTPs in the food supply chain dates further back in time.

For decades already, EU food producers have complained about increasing concentration on the purchasing markets for food in Europe, aggressive bargaining on the part of retail chains. Stories of ever more pressing requirements for low prices and dubious commercial practices such as unfair use of proprietary information and unilateral changes to contract terms have been reported both by media and in a steady flow of national policy reports and investigations, some dating back to the 1990s (UK Competition Commission, 2000; Nordic Competition Authorities, 2005; Baltic International Center for Economic Policy Studies, 2006; UK Competition Commission, 2008; EIM, 2009; Spanish Competition Authority, 2010; TISCO, 2012; SEO Economisch Onderzoek, 2013; EY, Arcadia International and Cambridge Econometrics Ltd, 2014). Complaints of UTPs put the blame on growing concentration in the food supply chain, especially the growing power of buyers (retailers and processors) against suppliers (primary food producers and processed food manufacturers). The problem is thus framed loosely as an issue of buyer power and related concepts of superior bargaining power or economic dependency. As a result, questions have been raised about the role of competition law in stopping and preventing such practices and addressing the issue of power at the root of the problem. Members of the European Parliament have pressed for enforcement of the competition rule. ${ }^{4}$

The response of the European Commission on this topic can be described as careful, but this statement requires some qualification: notably, whereas some

1 Directive (EU) 2019/633 of the European Parliament and of the Council of 17 April 2019 on unfair trading practices in business-to-business relationships in the agricultural and food supply chain, OJ L 111, 25.4.2019, p. 59-72.

2 European Commission, Proposal for a Directive of the European Parliament and of the Council on unfair trading practices in business-to-business relationships in the food supply chain $\operatorname{COM(2018)~} 173$ final.

3 The agricultural supply chain includes agricultural products which are not destined for consumption as food, e.g. cut flowers.

${ }^{4}$ European Parliament resolution of 19 January 2016 on the Annual report on EU Competition Policy (2015/2140(INI)), para 104 and European Parliament resolution of 7 June 2016 on unfair trading practices in the food supply chain (2015/2065(INI)) [2018]OJ C 086/05). 
directorate-generals (hereinafter: DGs) have taken proactive steps regarding UTPs, the directorate general for competition has been rather guarded in its approach. When it comes to the issue of buyer power, or concepts of superior bargaining power, economic dependency, or unfair trading practices in the food sector, the Commission's approach, at least that of the competition division, has consistently been set in favor of non-intervention. Concerned with chilling competition, and wary of adverse effects on consumers, DG competition has been careful to study the issue extensively, e.g. by commissioning research, such as the one by EY et al. (2014), on the impact of concentration on choice. However, the competition directorate general has refrained from more far reaching interventions, for example as it has done in other sectors in the past. ${ }^{5}$ Notwithstanding the 2010 introduction of a $30 \%$ market share threshold on the buyer side for the assessment of vertical restraints, when it comes to UTPs in the agri-food sector, at the EU level, no big case was pursued, no formal sector inquiry was opened, and no guidelines were introduced. ${ }^{6}$

Despite the reserved stance of the competition directorate general, the field of UTP regulation has not been still. Over the past two decades, a number of developments have sought to fill the antitrust enforcement gap. The 'action' has taken place at the national level and in the field of sectorspecific regulation, notably the Common Agricultural Policy (CAP). With respect to the latter, the competition law framework applicable to agricultural producers has arguably been weakened in order to allow producers to make up for the lack of bargaining power. At the Member State level, EU states have introduced of a wide variety of laws, in particular stricter competition rules, rules on business-to-business UTPs, and rules specifically for the food sector. By introducing such laws, Member States have thus chosen to circumvent the limitations of the main EU competition law framework.

There is no doubt that these laws deviate from 'mainstream' EU competition law, yet in the EU they are the norm rather than the exception. In a Union of 27 Member States, only four Member States have no specific regulation, with some Member States having several types of legislative instruments in place, alongside private regulation (Cafaggi and Iamicelli, 2018). ${ }^{7}$ Given this

5 The Directorate General for Competition has carried out market inquiries for energy (2005), retail banking and business insurance (2007), pharmaceutical sector (2009), and e-commerce (2015).

6 The 2010 Block Exemption Regulation on Vertical Restraints did reflect the issue of buyer power by introducing a 30\% threshold on the purchasing side (Regulation (EU) No 330/2010, 2010). However, there is limited information about the actual practical significance of this stricter regulation in the context of unfair trading practices in the food supply chain.

7 According to the report, prepared for the Joint Research Center, only 4 EU Member States currently have no legislation addressing UTPs in the context of a B2B relationship. These are Estonia, Luxembourg, Malta, and the Netherlands. The authors note that Belgium, 
background, Directive 2019/633 seems less revolutionary than at first blush. In fact, it may be seen as a belated response from the EU to an issue on which most EU Member States have already introduced their own legislation.

This article tells the story of how measures tackling a policy problem perceived to be on the periphery of mainstream competition law, namely UTPs in the context of power imbalance, can have a counterproductive effect when they are not coordinated with the competition law approach in that area. It furthermore reveals important side effects arising from this lack of coordination. It is a story of how such a problem, only partially addressed, moves across policy areas, jurisdictions and legal disciplines; how the task of regulating it at the national level in the context of an integrated market becomes more complicated over time, and what perverse effects arise along the way. Using the typology of counterproductive regulation developed by Grabosky (1995), it sheds light on some of the regulatory pitfalls that emerged in the context of efforts to regulate business-to-business UTPs in the food sector in the past two decades.

The article firstly explains the background of the problem and the issue of UTPs in the agri-food supply chain. Secondly, it maps the various legislative developments which have taken place at the EU Member State level. Thirdly, by referring to Grabosky's (1995) regulatory studies typology of counterproductive regulation, the article focuses attention on some of the perverse side effects which arise when regulation of power imbalances and UTPs occurs at the national level in the context of an integrated market like the EU. In light of the analysis, it expresses doubt that these pitfalls will be fully corrected by Directive 2019/633 on UTPs in the food supply chain. The conclusion is that national legislative developments have not been able to make up for the lack of supra-national enforcement of EU competition law on this issue and may have exacerbated the problem at hand. The article concludes that supranational competition law enforcement can play a key role in addressing the fundamental problems underlying business-to-business unfair trading practices. It argues that this role cannot be played by other instruments in the context of an integrated market with multi-level governance. This article shows that while competition law may not be capable of solving all the problems with UTPs, it remains indispensable in safeguarding the proper functioning of the internal market as well as the interests of consumers and taxpayers.

Denmark, Finland, Sweden have legislation covering the issue to a more limited extent and that 20 Member States have legislation specifically tailored to the issue (Cafaggi and Iamicelli, p. 8) 


\section{The question of UTPs in the agri-food supply chain: a question for competition law or for other regulation?}

What is an unfair trading practice in the context of business-to-business relations? The preamble to Directive 2019/633, while shying away from providing a comprehensive definition, gives an indication of which practices may be considered unfair: 'Such practices may, for example: grossly deviate from good commercial conduct, be contrary to good faith and fair dealing and be unilaterally imposed by one trading partner on the other; impose an unjustified and disproportionate transfer of economic risk from one trading partner to another; or impose a significant imbalance of rights and obligations on one trading partner. Certain practices might be manifestly unfair even when both parties agree to them.'

According to Article 1 of Direcetive 2019/633, UTPs are 'practices that grossly deviate from good commercial conduct, that are contrary to good faith and fair dealing and that are unilaterally imposed by one trading partner on another'. According to the Directive 2019/633, the key driving factor of UTPs are the 'significant imbalances in bargaining power between suppliers and buyers' in the agri-food supply chain (Preamble, paragraph 1). Thus, UTPs are linked to the presence of power, but the Directive is careful not to equate this power to the power normally addressed by the competition rules. The text makes no reference to market power or a position of dominance; rather it seems to address a different kind of power, namely the relative bargaining power of buyers in the agri-food supply chain.

The rationale for the Directive, as well as other legislation aiming to combat unfair trading practices imposed in a business-to-business relationship, has been controversial in competition law scholarship (Scheelings and Wright, 2006; cf. Wakui and Cheng, 2015). Debates often emphasize the difficulties of defining fairness, or the need to weigh the pros and cons of intervening in bilateral business relationships where there is no market power, as well as the self-healing capacities of markets. As a result, competition law enforcement in the areas of UTPs or superior bargaining power has often been discouraged.

Turning to economic theory, however, one may consider the context in which UTPs take place. According to economic theory, in a competitive market with complete information, one-sided deals would not be a viable business model. Deviant traders would be punished by the market - a dissatisfied businessperson who has had a bad experience with another trader could 'vote' with her feet, seek a different contractual partner next time, and warn fellow traders not to contract with the deviant trader. This is the market mechanism in action - allowing for the bad contracts to be weeded out from the good 
contracts. However, the market mechanism fails in a market in which power is concentrated in the hands of few contracting partners and alternatives are hard to find. ${ }^{8}$ For instance, in a market in which there are limited outside options, the market will fail to discipline the deviant trader, at least for as long as exit is not possible. The concept of limited outside options is recognised in some legal systems (notably Germany) which regulate situations of superior bargaining power or economic dependency in the context of a bilateral relationship. However, this concept is not yet recognised as part of mainstream competition law at the EU level.

There are reasons to think that while some UTPs may be isolated events, a number of practices are simply a feature of the food supply chain, that is, they seem to occur systematically, as if they are part of the retailers' business model. Cafaggi and Iamicellli (2019) draw a distinction between 'isolated' and 'systemic' UTPs and note that the latter can be embedded in the supply chain governance, thus affecting a large number of actors at the same time. Evidence of such practices is to be found in the growing decision practice and jurisprudence at the national level. In Germany, the Competition Authority's investigation of Edeka regarding so called 'wedding rebates' is a case in point (Bundeskartellamt, 2018). Reports on the activities of UK Grocery Code Adjudicator also provide data on a variety of practices, such as requests for contributions and payment delays, which are tolerated by suppliers but not genuinely agreed (UK Groceries Code Adjudicator, 2020). Beyond the EU, one may consider the reports of the Australian Consumer and Competition Commission's cases against the 'Mind the Gap' scheme of supermarket Woolworths and supermarket Coles' so called 'Active Retail Collaboration' program (ACCC, 2014; ACCC, 2016b). These cases provide detailed evidence of practices such as retailers asking suppliers for cash contributions to the bottom line, payments for mergers, and charges for various services.

Furthermore, data on concentration gives credibility to claims of limited outside options. EU reports reveal concentration of power in the food supply chain, at processing level and at the retail level. According to a fact sheet prepared by the Directorate General for Agriculture in the EU, '[t]he market share of the top five firms (or C5 concentration ratio) in the EU food industry was at an average of 56\% in 2012 in 14 of the EU's Member States; [a]t the same time, in 13 Member States the share of the top five retailers exceeded 60\%' (DG Agriculture and Rural Development, Unit Farm Economics, 2017). By comparison, the concentration ratio for agricultural producers was at $0.19 \%$ in 2010 (DG Agriculture and Rural Development, Unit Farm Economics, 2017).

\footnotetext{
${ }^{8}$ Of course, there may be other causes of market failures such as e.g. the presence of information asymmetries.
} 
High concentration has also been suggested to be the case by other studies (Food Drink Europe, 2011).

Given these indications of the genuine presence of systemic UTPs in the EU agri-food supply chain, the question arises why the competition rules have not been more proactively applied. Several factors may help explain this outcome. One has to do with the possibilities under the existing EU competition law framework, notably with respect to the provision on abuse of dominance (Article 101 TFEU) and the rules on agreements in a vertical relationship (Article 101 TFEU). Here, it must be noted that while market shares in some Member States may be indicative of the presence of strong retailers, and possibly oligopolies, the market shares do not point to the presence of clear dominant positions in retail. Of course, the figures indicate aggregate levels of concentration; to measure buyer power, one would need to consider the options available to a supplier within a certain geographic market (which may be local for products which are perishable or expensive to transport, or which may be international for goods which can easily be shipped). This raises the question as to whether a position of dominance can be shown. Regarding the possibility of addressing UTPs under the rules on anticompetitive vertical restraints, there is limited evidence of such investigations being undertaken by the European authorities in the food supply chain in the past decades. This may have to do with the analysis under Article 101 TFEU being less focused on fairness and distributive justice and being more focused on efficiencies and outcomes for consumers instead.

The influence of economic reasoning on the policy problem framing may have also played a role. Anecdotal evidence suggests that economists in policy making consider UTP complaints (as well as UTP legislation) as a form of rentseeking by inefficient producers. Neoliberal economics puts trust in the market mechanism to weed out inefficient producers; if the market mechanism works well, efficient producers would not suffer from unfair trading practices. The question, of course, is whether inefficiency is the only plausible explanation for being susceptible to UTPs. It cannot be taken for granted that all producers who complain of UTPs are inefficient. Another question is whether the remedy that the market mechanism provides, namely exit of the 'inefficient' suppliers or consolidation on the supply side, is even desirable in view of the broader goals, and in view of long-term consumer welfare.

Rebalancing of market power via exit or consolidation of the supply side of the food supply chain is not necessarily a smooth and costless process. An important point with respect to farming is that entry and exit in this sector are a bit peculiar: that is, farming is often an inherited occupation and somewhat closed off to outside entrants (Gasson, 1986; Gale, 1993). Farmers, even when faced with insufficient earnings, e.g. due to UTPs or to their own 
inefficiency, may be reluctant to exit. This may be because exit from farming, as any other career change, depends on the opportunities and perceived utility of alternative employment, individual-level factors such as age and education, regional factors such as level of urbanization, but also emotional factors such as feelings of pride and autonomy (van Herck, 2009).

More generally applicable for the food supply chain is the issue of bankruptcy. This is a topic which is especially difficult for SMEs, where the livelihood of an entire family may be tied to the family enterprise. In the case of family farms and businesses, the issue of bankruptcy or restructuring the business, can have dramatic consequences not just financially but also psychologically as one might lose not only his or her income, but also status within the community (European Commission, 2007b). In its communication called 'Overcoming the stigma of business failure - for a second chance policy', the European Commission notes that, unlike in the US, in the EU there is a stigma associated with bankruptcy (European Commission, 2007b). Thus, both declaring bankruptcy and the costs and benefits of searching for alternative occupations are relevant factors to consider when interpreting data on exit rates of small suppliers in the agri-food chain. This research might help explain why the presence of UTPs or low prices does not necessarily induce exit of the most inefficient producers.

Quite different is the question whether leaving it to the brute market forces is the best way to address the problem of power imbalances. Arguably, letting companies exit is a rather drastic way of dealing with problems such as UTPs which occur as a result of such power imbalances. Farm exit means a loss of capacity in this sector; rebuilding such capacity, as in bringing outsiders back into agriculture, is not an easy process. One of the priorities for the common agricultural policy is to attract young farmers in order to ensure intergenerational renewal (European Commission, n.d., b). On the other hand, consolidation of farm holdings, although possibly more efficient in terms of productive efficiency and negotiating power, also carries risks related to increased supplier power. Solving one problem may thus create another problem which in itself may bring consequences much more unacceptable to society (loss of capacity, consolidation) than the costs related to UTP legislation.

These arguments do not seem to have had traction with the Directorate General for Competition of the European Commission. The latter has consistently emphasized that unfair trading practices do not fall within the scope of the competition laws (Chauve, 2019; cf. Valetti, 2018). Accordingly, DG Competition has not been proactive in its enforcement. For instance, a 2012 report on the activities of national and European competition law enforcers in the food sector for the period 2004-2012 lists over 160 enforcement actions: however, a closer look at the data provided reveals that few deal with the 
issue of buying power and unfair trading practices imposed by powerful buyers (European Competition Network Subgroup on Food, 2012). The study shows data on a couple of national enforcement actions against buyer cartels in Greece, Bulgaria, Latvia, and on abuse of dominance in Austria; however, the majority of the enforcement concerns horizontal cartels (European Competition Network Subgroup on Food, 2012). Following the adoption of stricter rules on UTPs by the majority of EU Member States, there is also vigorous enforcement in some of the jurisdictions which adopted such rules (Cafaggi and Iamicelli, 2018, p. 36-37). Notable against this backdrop is the paucity of action at the EU level. At the EU level, the policy choice was made to leave room for adopting diverging legislation at the national level and for enforcement at the national level, instead of intervening at the EU level with EU legal tools.

To further elaborate on the prevailing attitudes, it is worth examining the submissions by national competition authority representatives at the first meetings of the Joint Working Team on Milk (European Commission, 2010b, p. 28-30). According to the views expressed, competition law is not meant to 'interfere in the bargain struck between contractual parties, in the absence of proven competitive harm' (European Commission, 2010b, p. 28-30). As to unequal bargaining power, it 'often leads to commercial dealings, which are unlikely to restrict competition to any significant extent, but which appear to be unjust, unfair or undesirable from a social or political point of view' (European Commission, 2010b, p. 28-30). According to a number of national competition authorities, competition law enforcement should 'tackle buyer power to the extent that it harms, or could potentially harm, the competitive process and thereby consumer welfare' (European Commission, 2010b, p. 28-30). Summing up, the response has been to maintain a strict separation between competition law and UTP legislation: 'The exercise of buyer power in an anti-competitive manner is contrary to EU competition law where there is a proven detriment to downstream consumers. Much of the current political interest is in fact focused on issues of 'unequal bargaining power' which should be distinguished from issues of 'buyer power', and actually highlights problems faced by small suppliers in the context of contractual negotiations with stronger buyers. [...] Most Member States have already enacted specific laws dealing with such issues and have established legal protective mechanisms for all contractual parties in the context of their commercial laws' (European Commission, 2010b, p. 28-30).

This section has aimed to explain the state of play in terms of discourse regarding UTPs. It has aimed to show that DG competition has not been proactive in this field, but also to critically question this policy choice. One consequence of this choice has been that Member State legislators and authorities have 'taken matters in their own hands'. In more than half of the Members States with special legislation, tackling unfair trading practices, 
as well as possible abuses of buyer power, superior bargaining power, and economic dependency more generally, has been delegated to competition authorities (Cafaggi and Iamicelli, 2018, p. 22-23). In a number of Member States, the legislation was also embedded in competition law, whereas others have built upon pre-existing normative frameworks developed under contract law, consumer protection or unfair competition doctrines (Cafaggi and Iamicelli, 2018). As a result, numerous approaches to the issue of UTPs have emerged, which will be mapped in the following section.

\section{The rise of stricter unilateral conduct rules in the EU: mapping national approaches}

When it comes to the implementation of Directive 2019/633, Member States are not writing on an empty canvas. In fact, most EU Member States already have some legislative solution to the problem of UTPs imposed in the context of buyer power. In the past 15-20 years, more than ten Member States have enacted special laws or regulations to deal with the issue of buyer power in the food supply chain or the unfair trading practices that retailers are accused of. ${ }^{9}$ Whether sector-specific or general, the laws generally come in one or two varieties: as amendments of the competition law (e.g. as lower market dominance thresholds) or as amendments of the contract or commercial law (e.g. by introducing special rules on business-to-business transactions or by extending the consumer protection rules to small businesses). Sometimes there is only a competition law amendment or a commercial law which shares similarities with consumer law, and sometimes there are both. As mentioned above, in a European Union of 27 Member States, all but four Member States (Estonia, Luxembourg, Malta, and the Netherlands) currently have some sort of legislation (Cafaggi and Iamicelli, 2018, p. 8). For the rest, the picture is varied: some have legislation addressing a limited number of UTPs, whereas others have a mix of several types of legislation in place that aim to solve the issue of UTPs in the food supply chain.

${ }^{9}$ Examples of more recent adopters include: Slovakia (on and off since the early 2000s see further in Section V.1.), Hungary (2009), Latvia (2009), Lithuania (2009), Romania (2009), Belgium (2010), Czech Republic (2010), Italy (2012), UK (Code and Ombudsman: 2013), Bulgaria (2015), Ireland (2016), Poland (2017), Slovenia (2018). Some Member States have introduced several pieces of legislation, for example France, which introduced the Loi Egalim in 2018 (loi du 30 octobre 2018 pour l'équilibre des relations commerciales dans le secteur agricole et alimentaire et une alimentation saine, durable et accessible à tous). 
Classifying these laws presents a challenge: some of them target particular UTPs, mostly by prohibiting them, others focus on the issue of power imbalances, e.g. buyer power, economic dependence or superior bargaining power. Many of these laws can be loosely qualified as 'stricter unilateral conduct rules', an umbrella term used in Article 3(2) of Regulation 1/2003. ${ }^{10}$ However, as becomes clear, focusing only on competition law amendments does not reveal the complete picture of legislative activity across the EU.

The table below presents a mapping of the types of legislation available compiled on the basis of existing reports supplemented with research by the author. It indicates Member States which have both stricter competition rules, unfair business-to-business legislation (be it sector-specific for food or retail, or general), Member States with both (upper left quadrant), and Member States with neither (lower right quadrant). It is important to note that in some of the Member States with neither of the two types of developments, there may be private regulatory initiatives such as industry codes of conduct. For instance, between 2013-2019, the Supply Chain Initiative - a private self-regulatory initiative stimulated by the European Commission - was available in all Member States and provided an extra normative layer to an already complex legal framework (European Supply Chain Initiative, n.d.). Finally, there are some additional developments, such as the Loi EGalim in France, which, although concerned with UTPs, moves into the area of price regulation. ${ }^{11}$

A regulatory landscape so varied raises questions about market integration and the level playing field. In a field of law which aims for harmonization such as EU competition law, the fact that so many Member States have introduced competition law amendments is significant. Importantly, this is not an 'inherited situation', i.e. of divergent rules which existed prior to becoming a Member State of the EU. These are rules which have been introduced despite the presence of EU competition law; for the majority of Member States, this new legislation has been introduced after the harmonization efforts accompanying the entry into force of Regulation 1/2003. Based on the mapping, it is evident that most competition laws at the national level are already different from EU competition law, at least with respect to unilateral conduct rules, if not also with respect to Article 101 TFEU. ${ }^{12}$ The latter is important because,

10 Council Regulation (EC) No 1/2003 of 16 December 2002 on the implementation of the rules on competition laid down in Articles 81 and 82 of the Treaty [2003] OJ L 1/1. The article allows Member State to adopt laws stricter than Article 102 TFEU with respect to unilateral conduct engaged in by undertakings.

11 Loi n 2018-938 du 30 octobre 2018 pour l'équilibre des relations commerciales dans le secteur agricole et alimentaire et une alimentation saine, durable et accessible à tous.

12 Here, it should be noted that UTPs are fundamentally about vertical relations. Vertical relations, which are already regulated by Article 101 TFEU, are now subject to the additional 
unlike for Article 102 TFEU, room for deviations from the application of Article 101 TFEU has not been provided in Regulation 1/2003. A possible distortion of the approach to vertical restraints is thus one questionable aspect of this development. Another issue is whether these approaches are at all effective solution for the UTP problem, given the integrated nature of European markets. Here is where the counterproductive typology lens can offer useful insights. These will be discussed in the sections that follow.

Table 1. Stricter competition rules and UTP legislation for B2B in the EU

\begin{tabular}{|c|c|c|}
\hline & $\begin{array}{l}\text { YES } \\
\text { Consumer protection extended to } \\
\text { B2B } B^{1} \text { (or other legislation covering } \\
\text { UTPS in B2B) }\end{array}$ & $\begin{array}{l}\text { NO } \\
\text { Special contractual provisions } \\
\text { on B2B or UTPs or extension } \\
\text { of consumer protection to B2B } \\
\text { (general contract law applies) }\end{array}$ \\
\hline $\begin{array}{l}\text { YES } \\
\text { Stricter rules on unequal } \\
\text { bargaining power in } \\
\text { competition law }{ }^{2}\end{array}$ & $\begin{array}{l}\text { Austria (all UCPD provisions } \\
\text { superior bargaining power } \\
\text { sum }^{3}\end{array}$ & 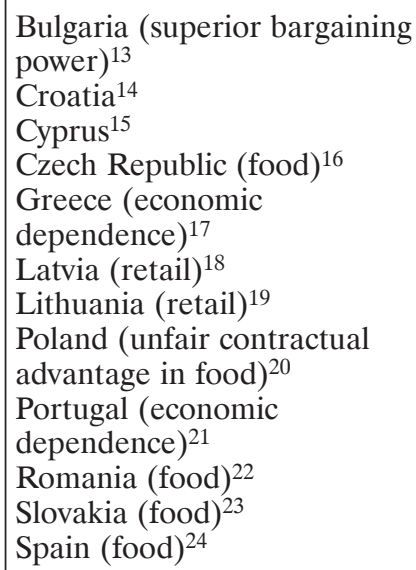 \\
\hline $\begin{array}{l}\text { NO } \\
\text { Stricter competition } \\
\text { rules (general } \\
\text { competition law } \\
\text { applies) }\end{array}$ & $\begin{array}{l}\text { Belgium (some Annex I UCPD } \\
\text { practices) } \\
\text { Denmark (aggressive and } \\
\text { misleading practices, UCPD) }{ }^{26} \\
\text { Ireland (food) } \\
\text { Sweden (all UCPD provisions) } \\
\text { Sw } \\
\text { UK (food; Grocery } \\
\text { adjudicator) }\end{array}$ & $\begin{array}{l}\text { Estonia } \\
\text { Luxembourg } \\
\text { Malta } \\
\text { Netherlands }\end{array}$ \\
\hline
\end{tabular}

1 This column draws on the results from a European Commission report (2016c, footnote 13 on p. 10).

2 This row partially draws on College of Europe et al. (2014).

$3 \S 1(1)$ of the Federal Act amending the 1984 Federal Act against Unfair Competition.

4 Article 4(3) of the Cartel Act.

5 Articles L. 121-1, I and III and L. 121-1-1 of the Consumer Code.

fairness criteria, required by national law and Directive 2019/633. The relationship between these legal frameworks remains unclear although clashes are foreseeable (Daskalova, 2019). 
6 Article L 420-2 of the Code de Commerce. Before 2010, France had a specific provision on economic dependence in civil law (Article L. 442-6), which was abolished. The existing provision also targets economic dependence under largely similar criteria. Due to the stringency of these criteria, however, enforcement remains sparse (College of Europe et al., 2014).

7 Section 3 of the Unfair Competition Act (UWG).

8 Article 20 Gesetz gegen Wettbewerbsbeschränkungen (GWB).

9 Act CLXIV of 2005 on Trade and Act XCV of 2009 on the Prohibition of Unfair Trading Practices vis-à-vis the Suppliers of Agricultural and Food Products.

10 Art. 62 Law Decree 24.1.2012, $\mathrm{n}^{\circ}$ 1; also, specifically for the agricultural sector: Law-decree 24.1.2012, Nr. 1 as amended by Law 24.3.2012, Nr. 27, concerning commercial (B2B) transactions in the field of agri-food products.

11 Art. 9, Law 18.6.1998 Nr. 192 on sub-supply relationships in productive activities.

12 Zakon o kmetijstvu (ZKme-1) as amended in 2018.

13 Article 37a on Superior Bargaining Power of the Act on Protection of Competition (Bulgarian State Journal No. 102 of 2008).

14 Laws on Trade Nr. 87/08, 96/08, 116/08, 76/09, 114/11, 68/13.

15 Cyprus Protection of Competition Act (Law 13(I)/2008).

16 Act on Significant Market Power in the Sale of agricultural and Food Products and Abuse thereof, amended with Act No 50/2016.

17 Article 16 of L. 2000/1991.

18 Section 13(2) related to "Prohibition of the Abuse of Dominant Position" of Latvian Competition law, introduced in 2009; As of 2016, there is also the Unfair Retail Trade Practices Prohibition Law.

19 Law on the Prohibition of Unfair Practices of Retailers of 22 December 2009 (amended on 17 December 2015).

20 Polish Act on Combating Unfair Use of Contractual Advantage in Trading in Agricultural and Food Products 2017.

21 Portugal Decree-Law no $166 / 2013$ of 27 December 2013.

22 Law 321/2009 on food marketing.

23 Law $362 / 2012$.

24 Law 12/2013 on measures to improve the functioning of the food chain (Ley 12/2013 de medidas para mejorar el funcionamiento de la cadena alimentaria).

25 Chapter 4 of Loi du 6 avril 2010 relative aux pratiques du marché et à la protection du consommateur.

26 The Marketing Practices Act Consolidated Act no. 58 of 20 January 2012 as amended by section 33 of Act no. 1231 of 18 December 2012; section 5 of Act no. 1387 of 23 December 2012 and section 1 of Act no. 378 of 17 April 2013.

27 SI No 35 of 2016 Consumer Protection Act 2007 (Grocery Goods Undertakings) Regulations 2016]

28 Section 1 of the Marketing Practises Act (2008:486).

29 Groceries Code Adjudicator Act 2013. Note: the UK is not a member of the EU as of 1.02.2020.

Source: Own research.

\section{The counterproductive regulation typology}

The legislative developments with respect to UTPs in the EU agri-food supply chain in the EU seem to fit the script of various scenarios of 'counterproductive regulation' - a situation in which the regulatory intervention aggravates the policy problem (Grabosky, 1995). A typology of this form of 'regulatory iatrogenesis' $^{13}$ is discussed in a seminal article by regulatory scholar Peter

13 Disease brought about or aggravated by medical intervention. 
Grabosky (1995). Based on his extensive study of regulatory failures, Grabosky identifies five types of regulatory intervention which tend to backfire. The scenarios in Grabosky's framework include: 1) escalation, 2) displacement, 3) over-deterrence, 4) perverse incentives and 5) misunderstanding opportunity costs. These scenarios are cautionary tales of how regulatory efforts can backfire. The typology will be presented briefly below. The scenarios will be applied to the regulatory efforts addressing UTPs in the remainder of the article.

The first type of counterproductive regulation leads to escalation. Here one can consider the example of regulation aimed at solving a problem (e.g. eliminating UTPs), which inadvertently escalates the issue (e.g. increases the number of UTPs or the severity of the consequences for suppliers). The second type, displacement, occurs when regulation, instead of solving the problem, shifts it to another policy area or another geographic area. This may happen when parties engage in forum shopping and trade diversion in order to avoid UTP legislation, or when the UTP issue creates problems for achieving goals under the Common Agricultural Policy. The third type of counterproductive regulation leads to over-deterrence due to failure to properly 'calibrate' regulation. For example, regulation aimed at decreasing a certain practice might decrease the practice in question by too much, thus bringing it to a level that is not desirable. In the case of UTPs, one may imagine that some contracting practices which are fair and efficient may be avoided for fear of infringing UTP legislation. The fourth type, perverse incentives, is a scenario featuring well known regulatory pitfalls such as moral hazard. In this scenario, regulation of UTPs may decrease incentives by producers to be more efficient, while not decreasing incentives for companies to bargain hard on the price. The fifth type, opportunity costs, refers to the idea of regulation striving for a perfect result to the point where the marginal costs of securing additional compliance are not justified. Arguably, the opposite scenario has unfolded with respect to UTPs, namely a rigorous focus on infringements perceived to directly affect consumer welfare might have led to the neglect of policy issues which do not directly affect consumer welfare, such as UTPs. ${ }^{14}$ There is no concrete evidence of the latter except for the obvious lack of cases undertaken at the EU level so this scenario will not be discussed in further detail; however, the article will nonetheless address the question of enforcement priorities in order to argue that more rigorous enforcement could have been undertaken.

14 Opportunity costs have possibly played an important role in shaping the response of some enforcers to complaints about UTPs in the food supply chain. Competition authorities which have focused on consumer welfare may have accordingly deprioritized complaints about unfair practices imposed on a business. This could have lead to a counterproductive result in that some cases have been systematically deprioritized. 
Grabosky's framework may not exhaust the topic of counterproductive regulation but it provides a useful frame through which individual Member States' interventions with respect to UTPs in the food supply chain can be analyzed. In considering stories from the European Member States' experience with regulating UTPs in the agri-food supply chain, one can find evidence of a number of scenarios described under the various categories of counterproductive regulation in Grabosky's typology. These examples will be discussed in the sections that follow.

\section{Displacement: problem moving, but not disappearing}

In Grabosky's typology, one of the ways in which regulation can backfire is by displacing the problem to 'other areas within or beyond a regulatory jurisdiction or policy domain' (Grabosky, 1995, p. 351). For instance, companies may choose to move operations to another country to avoid regulation, thereby exporting the problem to a different jurisdiction instead of solving it. Another example of displacement is when the problem for one policy area is solved but a problem for another policy area is created. The idea of national regulation resulting in the problem being 'exported' to another jurisdiction or displaced another policy helps shed light on the ambivalent experiences of some Member States with stricter national legislation against UTPs in the food supply chain. The case of Slovakia illustrates how de facto and de jure circumvention can take place in the case of national legislation targeting UTPs imposed by multinational retail chains operating in an integrated market. The example of the Common Agriculture Policy shows how issues in one policy area (market regulation) affect other policy areas (e.g. the environmental regulation and agriculture).

\section{Forum shopping and trade diversion: limits to unilateral solutions in an integrated market}

At the turn of 2000-2001 - just four years before the country became a member of the European Union - Slovakia's food retail market experienced profound changes. The country, a member of the former Eastern Bloc which had been making strides in terms of economic development, was penetrated by foreign grocery retail chains (OECD , 2008). As with any major change, there were both winners and losers. While this development brought benefits for Slovak consumers in terms of low prices and more choice, concerns were raised about the power of the foreign chains - in particular, their buying power 
vis-à-vis Slovak suppliers. According to Slovakia's submission: 'This changed the long-time pattern of the Slovak retail trade considerably. As retail chains introduced new relations, cooperation forms and trade practices, discussion on contributions or defectiveness of their buyer power was opened' (OECD, 2008, p. 215). As a result of concerns about the buyer power and the practices of the retail chains, there was social and political pressure for some sort of solution - be it legislation or regulation (OECD, 2008). In response to the pressure in 2003 Slovakia adopted the Act on Retail Chains - Act No. 358/2003 Coll. on Retail Chains - which incorporated an economic dependency criterion (OECD, 2008). The Act was to be enforced by the Ministry of the Economy, not by the competition authority (OECD, 2008).

The high expectations of the act were disappointed. Firstly, already in 2007 suppliers of food products started complaining about buyer power again (OECD, 2008, p. 215-216). These complaints led to a revision of the act and its replacement by another piece of legislation - the Act on Inappropriate Conditions in Business Relations which entered into force in 2008 (OECD, 2008, p. 215-216; Hodonova and Oleksik, 2010). The Act did not apply only to the food sector, but to any commercial relations (Hodonova and Oleksik, 2010). However, this Act was also found ineffective primarily due to difficulties in enforcing it - notably, the economic dependency criterion was difficult to satisfy (Hodonova and Oleksik, 2010). The authors argue that the main reason for the limited effectiveness of the Act was the fact that it adopted an 'economic dependency' approach; without a proper definition of and criteria for economic dependency, enforcement was encumbered (Hodonova and Oleksik, 2010). In 2010 Slovakia adopted yet another piece of legislation, namely the Unfair Terms in Foodstuff Act (Hodonova and Oleksik, 2010). ${ }^{15}$ The new act focused only on the food sector and removed the economic dependency criterion. It targeted specifically unfair contract terms and prohibited 30 types of such terms. The Act was to be enforced by the Ministry of Agriculture.

Yet, even this reform was unsuccessful. Already at the time of its adoption, many feared that the Act would damage domestic producers by prompting the retail chains to source from abroad (Hodonova and Oleksik, 2010). Less than a year after its adoption ( $1^{\text {st }}$ May 2010), the act was repealed on $12^{\text {th }}$ January 2011. The Ministry of Agriculture argued that following the adoption of the Act, multinational retail chains had started avoiding Slovak producers; by repealing the act, they hoped more national producers would have access to the domestic market (PMR Newsletter, 2011).

15 Act No. 140/2010 Coll. on Unfair Terms in Business Contracts between Reseller and Supplier of Goods that are Foodstuffs, in effect as of 1 May 2010. 
The Slovakian example shows how enacting stricter legislation in an integrated market can backfire. Evidence pointing to similar concerns comes from Ireland. According to Paul Gorecki, former member of the Irish Competition Authority, one of the reasons behind the lobbying for a code on UTPs in Ireland was increased competition from goods sold in the UK (Gorecki, 2009). When the euro appreciated, purchases across the border in the UK became more attractive in terms of price and retailers used sourcing from abroad as a threat in negotiation with local suppliers (Gorecki, 2009).

Beyond the issue of de facto circumvention of national law by means of a factual act such as sourcing from abroad, there is also the issue of de jure circumvention, for instance by means of a legal act. The public consultation by the Commission revealed that isolated cases of forum shopping by stronger contractual parties are observed in the EU: '[...] responses by public authorities to the Green Paper consultation reported isolated cases of 'forum shopping', i.e. a practice whereby the stronger contractual party unilaterally determines in which Member State, and hence under which regulatory framework, the contract is enforced in order to avoid the national frameworks with stricter measures against UTPs. This issue was explicitly raised by 5 Member States in the public consultation and during discussions in various stakeholder fora organised by the Commission' (European Commission, 2014a, p. 6-7).

The issue of displacement by means of forum shopping and trade diversion is now recognized. Some Member States' legislation on UTPs specifically applies to conduct taking place outside the national territory but producing effects inside their territory: Cafaggi and Iamicelli identify Ireland, the UK, Portugal and the Czech Republic among these states (2018, p. 12). The concern with displacement by means of forum shopping is also embedded in Directive 2019/633. Article 1(2) of the latter defines the scope of the Directive as covering sales where 'either the supplier or the buyer, or both, are established in the Union.' The Preamble of Directive 2019/633 elaborates: 'Suppliers in the Union should be protected not only against unfair trading practices by buyers that are established in the same Member State as the supplier or in a different Member State than the supplier, but also against unfair trading practices by buyers established outside the Union. Such protection would avoid possible unintended consequences, such as choosing the place of establishment on the basis of applicable rules. Suppliers established outside the Union should also enjoy protection against unfair trading practices when they sell agricultural and food products into the Union. Not only are such suppliers liable to be equally vulnerable to unfair trading practices, but a broader scope could also avoid the unintended diversion of trade towards non- protected suppliers, which would undermine the protection of suppliers in the Union' (bold added). 
This feature is arguably an important safeguard against forum shopping; nonetheless, questions regarding its practical significance can be raised. Given that the Directive aims at minimum harmonization ${ }^{16}$ and that the regulatory landscape is diverse (as established in Section 3 of this paper), forum shopping remains a threat to those Member States eager to maintain higher levels of protection for their producers. It should also be considered that the procedures for enforcement, as well as penalties for breach, remain national. Differences in terms of sanctions, length and type of procedure, and predisposition of courts and authorities (which may be sympathetic to certain arguments) might give rise to a more nuanced form of forum shopping. To guard against this pitfall, successful implementation of the provisions of Article 8 of the Directive on cooperation among authorities, sharing of best practices, and reporting will be key.

As to trade diversion, the threat remains for products which can be substituted from abroad. Within the EU, trade diversion may still take place to avoid stricter rules in some Member States. As to trade diversion to producers outside the EU, it also depends on how motivated and empowered producers outside of the EU will be to make complaints. It is not clear whether a national authority in the EU can start proceedings ex officio against a trader for imposing unfair trading practices against e.g. rose producers in Kenya exporting to the EU, and how it can obtain the data to prove that. Achieving a level playing field by means of minimum harmonization in an already rather diverse normative landscape cannot be assumed.

\section{Policy problem shifted to private law}

Another form of displacement is when the policy problem moves from one policy area or field of law to another. As with a bubble under the carpet, stamping on it with one's foot does not make the problem disappear; rather, it makes it move somewhere else. For those who advocate a narrow scope for competition law (e.g. only limited to proven efficiency losses) and who insist that issues of power imbalances, economic dependency, and superior bargaining power are not a problem for competition law, the entry into force of legislation specifically tackling UTPs has solved the issue. Thereby the UTP issue has shifted to areas of private law, such as contract law, business torts, and unfair trading law. However, it can be argued that shifting the UTP issue to private law in the absence of sufficient remedy for the power imbalance

16 According to Article 9 of Directive 2019/633, Member States 'may maintain or introduce stricter rules aimed at combatting unfair trading practices than those laid down' by the Directive as well as national rules on UTPs which are not within the scope of the Directive. 
issue has limited the usefulness of this approach. The unsatisfactory outcomes have, in turn, backfired on agricultural policy.

Most contract law systems recognize the principle of 'good faith'; this is evident from comparative initiatives such as the DCFR and the UNIDROIT Principles. A practice which contravenes basic norms of good faith and fair dealing may be challenged in court. In principle, practices which violate terms stipulated by the contract, or for which default rules exist, e.g. late payments or retroactive adjustments to trading terms which are not agreed by both parties, can be addressed in the context of private law proceedings. In practice, starting such proceedings is costly and cumbersome, and may carry additional perils in the context of unbalanced power relationships. Absent competition law enforcement or vigorously enforced public regulation, parties must start a contentious procedure, engage a lawyer, and provide evidence. The process costs time and money. Lodging a claim requires some rudimentary legal awareness which SMEs often do not have (Smith and Castellnou, 2015). In addition to these standard barriers for SMEs, there are other problems linked to power imbalances. There seems to be a climate of apprehension among traders who are in a position of economic dependency. Such traders fear that they would suffer commercial reprisals - e.g. in the form of delisting of products or other commercial retaliation should they submit a complaint. The latter is named in the 2013 Green Paper on UTPs as 'fear factor' (European Commission, 2013b). In fact, the fear of commercial retaliation is also a barrier to public enforcement, where the enforcers require testimony from suppliers. Apparently, the Australian Competition and Consumer Commission (ACCC) lost the case against supermarket giant Woolworths (Australian Competition and Consumer Commission against Woolworths Ltd [2016] FCA 1472) not for lack of a legal instrument but for lack of proof. Notably, the authority failed to convince witnesses to come forth, and thus to provide sufficient evidence; the small suppliers on whose behalf the case was brought did not want to come forth due to fear of commercial retaliation (ACCC, 2016a). Consequently, few claims are launched. Anecdotal evidence suggests that even in some jurisdictions with laws prohibiting economic dependency, cases tend to be launched by companies which are already bankrupt and therefore do not fear commercial retaliation. Thus, it is not only the market which fails to discipline the misbehaving trader; traditional legal courses of action - such as private law procedures or public law procedures requiring supplier testimony - are not easily accessible.

One might say that the problem is in private law and that the UTP issue has migrated to competition law. Such arguments rest on the understanding that the proper field for resolving UTPs is private law. Partially, this is true because UTPs ultimately concern relations between private parties. However, 
this argument only holds for those relations between private parties which have no effect on the market, or which are of an isolated, non-systemic nature. By contrast, the UTPs in question appear to be widespread and have the potential to influence consumer prices, farmer investment and profitability, and the nature of competition on the market in general. In these circumstances, providing more efficient procedures for dispute resolution does not change the systemic nature of the issue - as long as the power imbalances and the related fear of retaliation persist, there are likely to be barriers to enforcing one's legal rights.

Finally, it is worth considering the impact of UTP legislation on private law itself. UTP legislation and Directive 2019/633 aim to resolve the problem of UTPs partially by modifying the normative framework applicable to contracts and business torts, and by institutionalizing public enforcement for UTP disputes. Although Directive 2019/633 does not adopt a specific definition of fairness, the concepts developed under UTP legislation will likely influence other private law concepts and may spill over to contracts which are not meant to be regulated (e.g. concerning non-agricultural and non-food products, or related issues in business torts). This is another important side effect of UTP legislation.

\section{UTPs and the Common Agricultural Policy}

It is a peculiarity of the EU Treaties that farmer welfare is explicitly protected by law. The drafters of the EU Treaties (and all subsequent and preceding treaties) have instituted farmer welfare as an objective of EU common agricultural policy: Article 39(b) TFEU speaks of the need 'to ensure a fair standard of living for the agricultural community, in particular by increasing the individual earnings of persons engaged in agriculture'. This is an objective on par with other CAP objectives such as efficiency (Article 39(a) TFEU), food security (Article 39(d) TFEU) and consumer welfare (Article 39(e) TFEU). The Treaties' explicit commitment to farmer welfare means there is a legal basis and, in fact, a legal imperative, for policymakers to intervene in case this objective is compromised. It also means that the European Parliament may question whether the Commission is taking sufficient action in this area, something which the Parliament has done in the past (e.g. European Parliament, 2016a and 2016b).

It is important to realize that a number of EU goals depend on the proper functioning of the CAP; thus, compromising its functioning also threatens other objectives. Such is the case, for instance, with environmental goals (Hogan, 2017). Arguably, farmers are important in the EU not just because 
they produce food. Although originally established to ensure food security and free trade in agricultural products within the six Member States of the European Economic Community (Dam, 1967), the Common Agricultural Policy has evolved toward other objectives over time. In addition to producing food, today European farmers are responsible for providing other public goods: such as maintaining the traditional landscapes of Europe, preserving local knowledge about small-scale food production and traditional lore; and more generally, acting as custodians of the land (Agricultural Markets Task Force Annex E, 2016). Increasingly, sustainability and public health play an important role in the CAP (European Commission, 2020). Given that farmers are multi-faceted actors, their financial struggles jeopardize not only the traditional objectives of EU agricultural policy such as quantity, quality, and affordability, but also other policies which depend on farmers, such as public health and sustainability.

Farmers are a privileged actor in the food supply chain because their rights are specifically protected in the EU treaties. Directive 2019/633 is based on the EU competences in agriculture and is thus limited to suppliers of products identified in Annex I to the EU treaties and goods derived from these products. Reports on UTPs, however, note that these are practiced more generally encountered in the retail trade, not just in relations with farmers. For producers of other goods found in retail chains - e.g. cosmetics, household and cleaning products, etc. - the problem has migrated to whatever other area of law or regulation, if any, is concerned with their rights.

\section{Escalation: does more regulation on unfairness lead to more unfair outcomes?}

Regulation done wrong might escalate the risks or problems it is trying to eliminate. Examples include the case of stringent regulation of new risks which exacerbates existing risks, the phenomenon of so called 'creative compliance', and a situation in which under-enforcement results in irreversible damage (Grabosky, 1995, 348). Regulation - too much or too little of it - may cause a policy problem to escalate and thus become much more challenging to deal with than it would have been in the first place. The escalation perspective essentially asks regulators: is the problem likely to become worse because of the regulatory measures?

In the context of regulating UTPs in the food supply chain, one issue to consider is whether the regulatory instruments employed to tackle UTPs might actually aggravate the consequences for suppliers instead of alleviating 
them. As discussed above, trade diversion to foreign suppliers as a result of legislation may cause more harm to suppliers than the unfair practices themselves. Another issue to consider is that legislative instruments seeking to regulate certain contractual terms may shift the exploitative behavior to non-regulated terms.

One of these terms is price. Legislation on unfair trading practices rarely ever discusses price. ${ }^{17}$ In reality, discussions about unfair trading practices can hardly be seen as separate from discussions on price. Admittedly, some of the UTPs targeted relate to basic issues of procedural fairness - such as the ability to ask for a confirmation of the contract in writing, the right not to have the contract unilaterally and retroactively amended, and the right not to be threatened if one complains to authorities or enforces the contract in court. ${ }^{18}$ These UTPs are not in and of themselves profitable and are not directly linked to a monetary advantage; rather, they must be seen as enabling or facilitating certain behaviours which can have an impact on price. Practices such as asking for rebates after the fact, altering amounts payable for various services (shelf fees, marketing and promotion contributions), or returning unsold products, are certainly connected to the compensation ultimately received. Payment delays are also profitable insofar as they provide one party with free credit. These practices are economically advantageous for the party imposing them because they provide it with flexibility, additional monetary benefits, or absolve it of responsibility for commercial risk or failure. A prohibition on such practices deprives retailers from a source of profit or other advantages which can be expressed in monetary terms (e.g. the time value of money, in the case of payment delays, or the cost of disposing of garbage in case of unsold produce). In the face of regulation of these terms, an undertaking which has the power to impose such terms may decide to make up for the lost benefits by turning to non-regulated contract terms such as price, quantity, frequency of orders, or length of contract. A similar conclusion is reached by Wakui and Cheng (2015).

Contract terms and price are not necessarily substitutable from the perspective of the buyer but sometimes they can be. Limiting the possibility to extract a rent ex post, in light of actual sales performance, might lead purchasers to extract the rent ex ante. Inability to impose one unfair contractual term due to a ban might lead to imposing another, less strictly regulated term. Given the close link between retroactive demands for discounts, promotion money,

17 An interesting development in this respect is the Loi EGalim in France (loi du 30 octobre 2018 pour l'équilibre des relations commerciales dans le secteur agricole et alimentaire et une alimentation saine, durable et accessible à tous) which includes provisions on price negotiation.

18 Some UTPs, for instance, may relate to issues of intellectual property right protection, notably trade secrets. 
and price, powerful buyers may - when faced with rigid regulations on unfair trading practices - use their muscle to obtain lower prices or advantages by other means. In this case, suppliers would receive better quality contracts but might have to accept lower prices for their products or satisfy higher requirements with respect to the quality.

There is no readily available evidence on the impact on prices paid to producers in the aftermath of regulatory action on UTPs. However, a useful case to consider is the milk sector following the adoption about the Milk Package. The Milk Package was introduced following the crisis in the dairy sector in 2009. While not obliged, Member States were allowed to introduce strict requirements for the contracting process between milk producers and first purchasers; some Member States did take advantage of this possibility. The contracts would have to meet the following criteria: to be concluded in advance of delivery, be made in writing, include the price payable (static or calculated by a formula, the ingredients of which must be clarified in the contract itself), the volume and timing of deliveries, duration of the contract (including termination clauses for indefinite contracts), clarifications about payment periods and procedures, milk collection and deliveries, and force majeure provisions (Article 148 of Regulation 1308/2013 ${ }^{19}$ ). Where such contracts are mandated the Member states may establish minimum duration which may not be less than six months (Article 148 of Regulation 1308/2013). Essentially, these measures aimed to close possible gaps in the contract law regime which can be exploited by parties with a power advantage. These measures essentially limit the possibility of buyers misusing the freedom and flexibility afforded by contract law regimes in order to deliberately make the contract content uncertain and susceptible to exploitation.

Additionally, Regulation 1308/2013 aimed to address the bargaining power issue itself by allowing for collective bargaining by recognized producer organizations ${ }^{20}$ under certain conditions, notably that the volume of raw milk covered by the negotiations would not exceed $3.5 \%$ of total EU production and $33 \%$ of total volume produced or delivered in that Member State. ${ }^{21}$

19 Regulation (EU) No 1308/2013 of the European Parliament and of the Council of 17 December 2013 establishing a common organisation of the markets in agricultural products and repealing Council Regulations (EEC) No 922/72, (EEC) No 234/79, (EC) No 1037/2001 and (EC) No 1234/2007, OJ L 347, 20.12.2013, p. 671-854.

20 The provision only applies for producer organizations which are recognized under Article 152(3) of Regulation 1308/2013.

21 See Article 149 of Regulation 1308/2013. As per Article 149 (3), for Member States with volume of raw milk production of less than 500000 tonnes, the applicable threshold is $45 \%$ of national production. 
The Regulation also strengthened the status of interbranch organizations. ${ }^{22}$ Importantly, under Article 210 of Regulation 1308/2013, Article 101(1) TFEU does not apply to agreements and concerted practices of recognized interbranch organizations provided that they are notified and exempted by the European Commission for meeting some basic requirements. ${ }^{23}$ Such exemptions would be expected to strengthen the position of producers.

The Milk Package has been deemed relatively successful - its main goal was to strengthen the producers' position in the supply chain and, according to a report by the European Commission, ' $[t]$ here is evidence that it has done so to some extent, including through various other collective actions of producers going beyond the milk package' (European Commission, 2016b, p. 14). Currently, 13 Member States have introduced the possibility of compulsory contracts and, as a result, $41 \%$ of milk deliveries in the EU are covered by compulsory written contracts. Additionally, other laws or private voluntary codes of practice provide similar contracting conditions to the ones previewed in the Milk Package. Taking these other instruments into account, '95\% of total EU milk deliveries are covered under a formal agreement, in one form or another.' (European Commission, 2016b, p. 6)

The strengthening of producer organisations, in particular by providing the possibility of collective bargaining, has also been considered relatively successful. According to the survey carried out by the Commission, the main objectives of producer organisations are: better prices, more stable prices, and 'overall improvement of the producer's position in the supply chain', and ensuring milk collection for all members (European Commission, 2016b, p. 8). Of the respondents almost $70 \%$ reported having achieved a better price and about $60 \%$ reported partially achieving a more stable price. However, $20 \%$ of respondents informed that they had absolutely failed to achieve both of these goals (European Commission, 2016b, p. 8).

Despite these measures, and in addition to safety nets in case of dropping prices such as interventions on markets for skimmed milk powder, and direct income support, the perception remains that milk farmers in the EU continue to struggle. Media items portray the deplorable situation of dairy farmers; dairy farmers are frequently in the news in relation to protests related to their relationship with buyers and the low purchasing prices for milk.

22 See Article 157 (a) of Regulation 1308/2013. These are organizations which cover at least two different stages in the supply chain - e.g. producing, processing, and distribution.

23 The following remain incompatible: practices which may partition the markets within the Union; which may affect the market organization; which entail the fixing of prices or quotes; which may create discrimination; which may eliminate competition, or which are not proportionate. 
Does that mean price regulation is the next step? It might be. The Law EGalim enacted in 2018 in France requires that farmers propose prices on the basis of production costs and that interbranch organizations develop benchmarks of production costs and market indicators. The law empowers the Government to prohibit sales at a loss and various promotions of food products (such as two products for the price of one) and increases the scope of the prohibition for abusively low prices (French Ministry of Agriculture and Food, 2019). Such legislation in a country like France, which has a number of provisions on economic dependency and unfair trading practices, suggests that enacting UTP laws is not in itself a panacea for the problems with farmer prices. It is in itself an example of continued escalation which might aggravate the problem in new, yet to be discovered, ways.

\section{Perverse incentives: who benefits from the CAP?}

Regulatory intervention can create counterproductive effects when the regulation stimulates the behavior it aims to eliminate and when the benefits of regulation are not captured by those intended to benefit from them. Such is arguably the case with benefits flowing from the Common Agricultural Policy. The development of the CAP reform is an example of how measures which aim to correct markets can distort markets and incentives, while only partially benefitting those whom they aim to protect. The CAP developments seem especially fitting to the script of the 'perverse incentives' scenario in the typology of counterproductive regulation. This scenario covers cases of 'moral hazard' such as when rebates for toxic waste incentivize purposeful waste production and cases where the presence of insurance or a guarantee results in excessive risk taking on the part of the insured (Grabosky, 1995, p. 354-355). In Grabosky's view, the Reagan administration's policy of deposit insurance for small financial institutions combined with under-enforcement of prudential controls led to the Savings and Loan Scandal of the 1980s (Grabosky, 1995, p. 354-355). The story prompts one to wonder if the case of agriculture might be following the same path. The reflection below argues that CAP subsidies may have created perverse incentives which not only do not solve the problem of UTPs or the power imbalances enabling them, but which also imply inefficient use of public funds. That is, by keeping farmers subsidized, the Common Agricultural Policy (CAP) is indirectly subsidizing retailers. By shielding farmers from the effects of buyer power, the income support makes UTPs sustainable in the long run.

As already explained, the European Treaties have an explicit commitment to farmer welfare which is found in Article 39(b) TFEU. The way the CAP 
achieves this objective is by means of the following instruments: direct income support for farmers, market interventions ('market measures') in times of crisis, and rural development programs (European Commission, n.d., a). In addition to the direct payments, farmers can also apply for additional payments available under other schemes: a green payment, a young farmers' subsidy, support for small and medium-sized farms, and support for farmers in areas with difficult farming conditions. Although the CAP has become more marketoriented since the 1980s (Alons and Zwaan, 2016), EU farmers are among the most heavily subsidized in the world (ABC News, 2014). In fact, the CAP has traditionally absorbed more than $50 \%$ of the total EU budget - ranging from above $70 \%$ in the 1980s to just under $40 \%$ in recent years (European Commission, 2019a). ${ }^{24}$ Despite this, complaints suggest that CAP subsidies are not enough to ensure viability of farmers. This seems to present a paradox: how come farmers are complaining of insufficient income if they are already so heavily subsidized?

Figure 1. CAP expenditure as part of total EU expenditure (1980-2018)

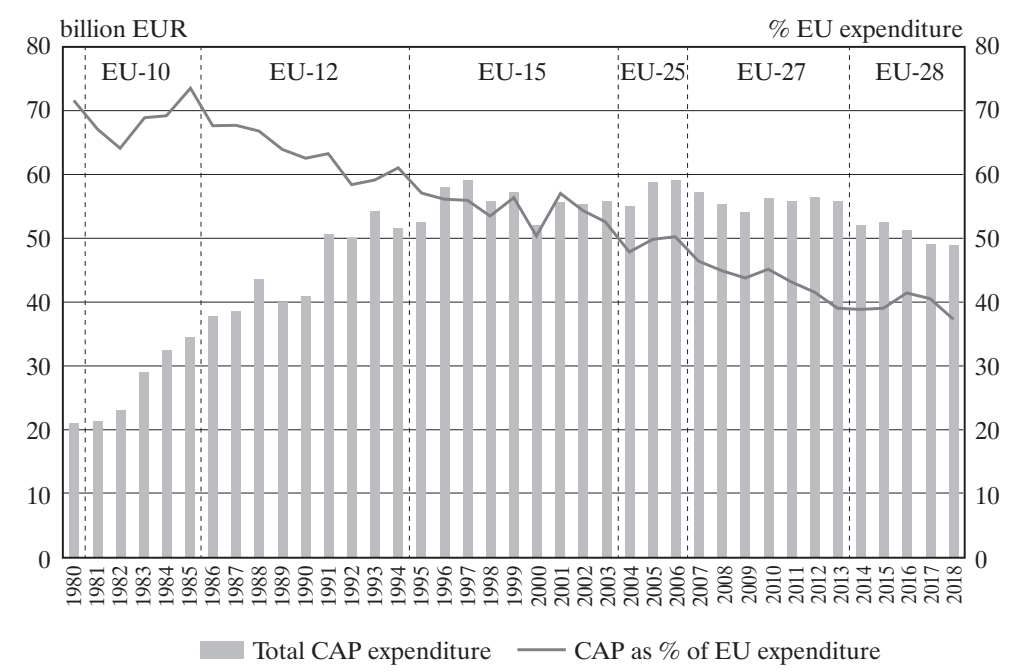

Source: European Commission. (2019). Common Agricultural Policy: Key graphs \& figures.

24 At their highest, farmer subsidies absorbed more than $70 \%$ of the total EU budget. The percentage has shrunk over time to just under $40 \%$ of the total budget, but the absolute sum of money spent on agriculture has grown due to the larger number of Member States. 
The answer may have to do with structural issues such as power imbalances. ${ }^{25}$ The economic argument goes that even a monopsony buyer would not push prices too low because it needs to secure a competitive supplier base; a rational buyer will therefore keep suppliers in business in order to stay profitable in the long run. But what about a buyer who knows that no matter how hard it presses the price, farmers will stay in business thanks to generous government support backed by a legal commitment to intervene? ${ }^{26}$ An intelligent buyer will learn to incorporate this knowledge and will adjust its strategy accordingly. Given a serious commitment by the public to continue to subsidize one's suppliers, it is only rational that the purchaser will take this into account just as a bank which knows it is going to be bailed out runs the risk of taking too much risk. There is no need to worry about starving the goose that lays the golden eggs - because the goose will be resuscitated, fed, and propped back on its feet thanks to generous taxpayers' support.

But there is more to this observation. If retail chains extract welfare from farmers, who as a result must be subsidized, it is evident that not only farmers benefit from subsidy payments. In a perverse chain of events, retailers benefit both directly and indirectly from CAP subsides. Indirectly, they benefit because they can exploit a stable supply source without concern about the long-run consequences. Directly, they benefit because the 'rents' they extract from dependent suppliers are - in a perverse way - the 'rents' that farmers receive from the taxpayers of the EU. According to an OECD Roundtable Report on Subsidies: 'Another weakness of the use of subsidies as a redistributive tool, rather than direct income taxation and redistribution, is that subsidies often miss their goals because they may end up being appropriated by agents that are not the intended beneficiaries. Again, aid to agriculture is a case in point.' (OECD, 2010, p. 39).

Subsidies and related support measures such as intervention measures may play a useful role in correcting market outcomes and achieving socially (or politically) palatable results. Yet, as it turns out, subsidy policies cannot be viewed in isolation from structural issues on markets, and thus, by implication, from competition policy. In this case, it is evident that the CAP cannot fulfill its goal of transitioning to a more market-based regime if suppliers must be 'bailed out' every so often.

25 It should be noted that, although the focus in this article is on buyer concentration, supplier power can also be an issue for producers in the agri-food supply chain. Notable is the strong position of suppliers of seeds, fertiliser and equipment.

26 Additional argument that is valid regardless of the presence of income support is that a monopsonist who lacks the knowledge about supplier cost structures or a monopsonist with short-term management horizons may indeed press too hard. The result is akin to 'killing off the goose that lays golden eggs', namely eroding a reliable and dependent supplier base, thereby also weakening the monopsonists' position. 


\section{Over-deterrence: how many pieces of legislation does it take to tackle UTPs?}

That strict standards may chill desirable behavior is a widely acknowledged concern in antitrust law and at the crux of debates about so called type I (under-enforcement) versus type II (over-enforcement) errors. ${ }^{27}$ This section draws attention to an important consequence of insufficiently addressing UTPs - the decision to strengthen the position of suppliers in the agri-food supply chain by limiting competition scrutiny in the context of the CAP. Reforms of the CAP framework over the past decade have resulted in serious limitations of competition law, all with the aim to strengthen producers against powerful purchasers. Whether these developments are to be preferred over intervention with competition law instruments can be questioned. The developments in question will be presented and discussed below.

Agriculture is special not only because of subsidies but also because primary food producers are subject to a special competition regime. In principle, the EU competition rules were meant to apply to primary agricultural producers - this is established in Article 42 TFEU. However, CAP legislation over the years has attempted to introduce qualified exceptions for primary producers from the cartel prohibition. ${ }^{28}$ The relationship between competition norms and CAP objectives has remained the subject of dispute: the nature and scope of such exceptions have been tested in a number of cases before the European Court of Justice. The result has been a fragile and not very clear compromise between the goals of agricultural policy and the goals of competition policy.

The Court has held that although the competition rules are meant to apply to the agricultural sector, the objectives of the common agricultural policy take precedence over competition norms (C-280/93 Germany v Council, ${ }^{29}$ para. 61; Case C-311/94 IJssel-Vliet Combinatie BV v Minister van Economische Zaken, ${ }^{30}$

27 The type I and type II error terminology originated in the field of statistics. In antitrust jargon, a type I error refers to under-enforcement, namely - letting harmful practices continue; a type II error refers to over-enforcement, namely - prohibiting harmless practices.

28 The very first CAP regulation addressed this possibility (Article 2 of Regulation No 26 of the Council of 4 April 1962 applying certain rules of competition to production of and trade in agricultural products [1962] OJ 30). See also Recital 7 of Regulation No 2200/96 which notes that 'in the face of ever greater concentration of demand, the grouping of supply through these organisations is more than ever an economic necessity in order to strengthen the position of producers in the market'.

29 CJEU judgment of 5 October 1994, Case C-280/93 Federal Republic of Germany v. Council of the European Union, ECLI:EU:C:1994:367.

30 CJEU judgment of 15 October 1996, Case C-311/94 IJssel-Vliet Combinatie BV v. Minister van Economische Zaken, ECLI:EU:C:1996:383. 
para. 31; C-137/00 Milk Marque and National Farmers' Union, ${ }^{31}$ para. 81; C-456/00 France v Commission, ${ }^{32}$ para. 33; C-373/11 Panellinios Syndesmos Viomichanion Metapoiisis Kapnou, ${ }^{33}$ para. 39 and in C-671/15 President of the Autorité de la concurrence $v$ Association des producteurs vendeurs d'endives, ${ }^{34}$ para. 37). In the C-671/15 Endives judgment, the Court held that under conditions of strict proportionality, an anticompetitive agreement which takes place within a single producer organization or association of producer organizations will fall outside the scope of Article 101(1) TFEU. The Court specifically mentions the presence of buyer power as an acceptable justification for the anticompetitive agreement (C-671/15 Endives, para. 65).

Claims about power imbalances and UTPs have provided an impetus to clarify the relationship between competition law and CAP objectives and have served as an important argument to strengthen the exemptions from competition law. The Court's judgment in Endives complements a trend in CAP legislation to strengthen exemptions from competition law in order to stimulate producer consolidation (C-671/15 Endives). Over the past decade, increasingly far-reaching derogations from the competition provisions have been introduced in the CAP. Starting with the Milk Package of 2012, there was the possibility of mandating written contracts and a derogation from Article 101 TFEU for certain collective bargaining agreements between recognized milk producer organizations and purchasers (European Commission, DG Agriculture, 2020). ${ }^{35}$ With the general CAP reform in 2013, further derogations from Article 101 TFEU were included in order to strengthen the position of producer organizations and associations for producer organizations. The possibility for recognized producer organizations ${ }^{36}$ and associations of

31 CJEU judgment of 9 September 2003, Case C-137/00 The Queen v. The Competition Commission, Secretary of State for Trade and Industry and The Director General of Fair Trading, ex parte Milk Marque Ltd and National Farmers' Union, ECLI:EU:C:2003:429.

32 CJEU judgment of 12 December 2002, Case C-456/00 French Republic v Commission of the European Communities, ECLI:EU:C:2002:753.

33 CJEU judgment of 19 September 2013, Case C-373/11 Panellinios Syndesmos Viomichanion Metapoiisis Kapnou v Ypourgos Oikonomias kai Oikonomikon i Ypourgos Agrotikis Anaptyxis kai Trofimon, ECLI:EU:C:2013:567.

34 CJEU judgment of 14 November 2017, Case C-671/15 Président de l'Autorité de la concurrence $v$ Association des producteurs vendeurs d'endives (APVE) and others, ECLI:EU:C:2017:860.

35 See also Regulation (EU) No 261/2012 of the European Parliament and of the Council of 14 March 2012 amending Council Regulation (EC) No 1234/2007 as regards contractual relations in the milk and milk products sector. This regulation was repealed following the entry into force of Regulation 1308/2013, OJ L 94, 30.3.2012, p. 38-48, notably Article 149.

36 The criteria for recognized producer organizations are defined in Article 152 of Regulation 1308/2013. 
producer organizations ${ }^{37}$ to collectively negotiate contracts for the supply of olive oil (Article 169 of Regulation 1308/2013), beef (Article 170 of Regulation 1308/2013), and certain arable crops (Article 171 of Regulation 1308/2013) was introduced subject to certain conditions. These requirements included that the producer organisation or association of producer organisations must be recognized by the competent authorities of the relevant Member State, must pursue 'one or more of the objectives of concentrating supply, the placing on the market of the products produced by its members or optimising production costs', must achieve efficiencies in the integration of activities, and may not negotiate for volumes exceeding $20 \%$ of the relevant market for olive oil (and respectively 15\% of the total national production in the case of arable crops, beef and veal) (European Commission, 2015). Additionally, producers cannot be members of more than one producer organization which bargains collectively on their behalf; whereas producer organisations are required to notify the volume of product covered by the collective bargaining to the competent national authorities (European Commission, 2015). Supply management measures were provided for ham (Article 172 of Regulation 1308/2013) and cheese (Article 150 of Regulation 1308/2013) with protected designation of origin or a geographical indication. A provision on so called 'crisis cartels' providing producer organizations and interbranch organizations to take collective measures in order to stabilize markets in case of disturbance (European Commission, 2013a). As evident, the scope of exemptions was subject to meeting specific requirements, among them efficiency gains.

The 2013 reforms did not put an end to the story. The CAP has once again experienced significant reform with the entry into force of the so-called Omnibus Regulation on January 1st, 2018 (Regulation 2017/239338). The Omnibus Regulation aims to further strengthen the position of producers for instance, by ensuring there is funding and support available for coaching initiatives to encourage farmers to join producer organizations. ${ }^{39}$ The

37 The criteria for associations of producer organizations are defined in Article 156 of Regulation 1308/2013.

38 Regulation (EU) 2017/2393 of the European Parliament and of the Council of 13 December 2017 amending Regulations (EU) No 1305/2013 on support for rural development by the European Agricultural Fund for Rural Development (EAFRD), (EU) No 1306/2013 on the financing, management and monitoring of the common agricultural policy, (EU) No 1307/2013 establishing rules for direct payments to farmers under support schemes within the framework of the common agricultural policy, (EU) No 1308/2013 establishing a common organisation of the markets in agricultural products and (EU) No 652/2014 laying down provisions for the management of expenditure relating to the food chain, animal health and animal welfare, and relating to plant health and plant reproductive material, OJ L 350, 29.12.2017, p. 15-49.

39 See for instance, the amendments to Articles 33, 34, and 35 of Regulation 1308/2013 explained in Article 4(1), (2) and (5) of Regulation 2017/2393. 
provisions on written contracts have been strengthened and expanded. In the case of milk producers, even where Member States choose not to mandate contracts, individual producers, POs or APOs, may require a written contract (Article 148 of Regulation 1308/2013 as amended by Article 4(8) of Regulation 2017/2393). This possibility is also open to producers, producer orgnisations, or associations of producer organisations, of other agricultural sectors (not only milk and sugar) thanks to an amendment of Article 168 of Regulation 1308/2013 (by virtue of Article 4(15) of Regulation 2017/2393). The valuesharing agreements which were previously only available for the sugar sector, have been further extended. Under a new Article 172(a), introduced by the Omnibus Regulation, farmers, associations of farmers and their first purchasers, are now allowed to establish 'standard value sharing clauses' - agreements about how to cope with changes in market prices of the products, including bonuses and losses (Article 4(17) of Regulation 2017/2393). This option is also available to interbranch organizations (Article 4(12) of Regulation 2017/2393).

Perhaps most importantly, the Omnibus Regulation expands the scope of derogations from competition law, relieves these derogations from the conditions of productive efficiency, and makes these derogations explicit. For instance, Article 152 of Regulation 1308/2013 which deals with producer organizations now includes an explicit derogation from Article 101 TFEU (by virtue of Article 4(10) of Regulation 2017/2393). The collective bargaining exemption is thus not only available for specific sectors such as milk, beef and veal, olive oil and certain arable crops, but for all recognized producer organisations and associations of producer organisations. Importantly, the efficiency criteria and market share thresholds, which featured in the 2013 reforms, have been abandoned.

According to Article 209(1) of Regulation 1308/2013, as amended by the Omnibus regulation of 2018, Article 101(1) TFEU does not apply to agreements, decisions and concerted practices of a variety of farmer organizations (farmers, farmers' associations, or associations of such associations, or producer organisations recognised under Article 152 or Article 161 of the CAP Regulation, or associations of producer organisations recognised under Article 156 of the CAP Regulation 1308/2013) so long as the agreements do not result in an obligation to charge an identical price or which exclude competition. Importantly, under this regime the presumption is that the activities in question are legal without a prior decision on the matter being necessary (Article 209(2) of Regulation 1308/2013, as amended in 2018). ${ }^{40}$ Furthermore, the conditions for crisis cartels, introduced with the reform in 2013, have been relaxed. Under the new rules, crisis cartels

40 However, Article 151(2) of Regulation (EU) No 1308/2013 provides that authorities may intervene in individual cases and decide that an exempted activity must be modified or 
are open not only to recognized producer organisations, associations of producer organisations, and interbranch organizations but more generally to farmers, farmers' associations, or associations of such associations (by virtue of Article 4(21) of Regulation 2017/2393 amending Article 222 of Regulation 1308/2013). Following the Omnibus regulation, the preconditions for granting an exception have been scrapped, so a crisis cartel is no longer a measure of last resort. ${ }^{41}$ These are far reaching exemptions from competition law scrutiny.

The measures under the CAP aim to consolidate producers in certain sectors, thereby creating producer power. This approach of fighting fire with fire may help to solve the problem of producer profitability. However, it may create problems for consumer welfare. A situation in which both producers and retailers are concentrated raises questions about possible increases in prices to consumers and a decrease in demand. As one CAP scholar puts it:

'the attempt to strengthen producers' organisations, rather than curbing the power of the oligopolistic downstream sector, bears the risk of double marginalization, which might eventually be costly for consumers and lower the demand for products such as fruit and vegetables' (Bureau, 2012, p. 319).

The 'double marginalization' mentioned in the quote refers to a situation in which both suppliers and producers impose their respective mark-ups. The result is bad for consumers because neither party constrains the other nor is willing to absorb the other's markup. When both side have power, the consumer might pay a double mark-up. Proposals to empower one side of the market in order to fight concentration on other markets therefore remain controversial from a mainstream competition viewpoint. Even proponents of such solutions, notably John Kirkwood, cautions that authorizing supplier cartels as a solution to buyer power should be allowed only under very strictly defined circumstances (Kirkwood, 2014, p. 51-52). According to Kirkwood, supplier cartels could be justified in the presence of buyer power if three cumulative requirements are met: the suppliers are faced with legally acquired, substantial, persistent, and durable monopsony power; the suppliers' cartel will engender procompetitive effects downstream; and no downstream market power will arise as a result of the collusion (Kirkwood, 2014, p. 51-52). It is not clear whether these conditions are met in the context of the EU agri-food

discontinued if this is necessary to protect competition or CAP objectives. The burden of proof is on the competition authority.

41 See Article 4(21) of Regulation 2017/2393 amending Article 222 of Regulation 1308/2013. The requirement that a crisis cartel can only be approved if the Commission has 'already adopted one of the measures referred to in this Chapter, if products have been bought in under public intervention or if aid for private storage referred to in Chapter I of Title I of Part II has been granted' (former Article 222(2) of Regulation 1308/2013) has been deleted. This means there is a shorter pathway to granting approval for limitation of competition. 
supply chain. In the absence of efficiency requirements, it is also more difficult to verify whether that is the case.

Derogations from competition law in the field of agriculture, combined with possibilities for consolidation are arguably a case of overdeterrence when one considers that they are happening against the backdrop of legislation on UTPs and stricter competition laws at the national level. They might also be seen as a form of escalation, and policy displacement when one considers the likely impact on consumers. Consumer welfare is also amid the CAP goals; specifically, sub-paragraph (e) of Article 39 TFEU establishes the goal that 'supplies reach consumers at reasonable prices', thus requiring that the objective of increasing standard of living for the farming community be balanced against fairness to consumers. With an increased power for suppliers and no intervention against the bargaining power of the chains, consumers are likely to find themselves bearing the burden of paying for the sake of restoring balance upstream in the supply chain. This is in its way also problematic, considering that food is not a discretionary item but rather essential to the survival of every single human. It makes up a significant portion of the essential expenditures of consumers, with poor consumers spending a disproportionate amount of their income on food (European Competition, Network Subgroup on Food, 2012, p. 14-15). ${ }^{42}$

Striking a balance between the interests of producers, processors, distributors, and consumers is a difficult task. Keeping track of who bears the cost of regulation is also challenging. This section has shed light on the far-reaching adjustments made under the CAP in order to address the problem of power imbalances in the agri-food supply chain and the resulting UTPs. It is difficult to say whether the measures are overdeterrent, or simply overwhelming, because it is not clear to what extent they have been successful. Nonetheless, they invite reflection as to whether intervention with the tools of competition law would not have resulted in a better safeguarding of market mechanisms, efficiency, and consumer welfare.

42 According to the report based on data from DG Agriculture, EU consumers spent on average $14.1 \%$ of their total household budgets on food in 2011. However, there is a great disparity within Member States with consumers in Luxembourg spending 9\% of their income on food and consumers in Romania spending 33\% of their income on food. In general, poor consumers spend a higher percentage of their income on food than wealthier consumers and are likely to be hit harder by rising food prices. 


\section{Re-examining enforcement priorities}

In light of the foregoing considerations, it is worth questioning whether the EU competition regulators have made the correct enforcement choices regarding UTPs in the agri-food supply chain. As noted in the introduction, the European Commission has chosen not to intervene in matters related to UTPs with the instruments available under competition law. This is arguably a sensible approach if one considers that the issue of UTPs takes competition agencies outside the comfort zone of standard competition law enforcement. Nonetheless, the preference for non-enforcement is curious when contrasted with the courageous approach of the Commission to similar concerns in other sectors.

One such concern is with the use of private labels by retailers. This issue essentially concerns the customer-competitor conflict between supermarkets and their suppliers. One controversial aspect of private labels is that the retailer is in the position to adjust the pricing structure, display and promotions of both its own brand product as well as the branded products, to the benefit of its own label. Suppliers have also complained that over time supermarkets have replaced 'tier-B' brands with own label products. These issues have been discussed in the competition law literature for more than a decade already (Ezrachi and Bernitz, 20019; Ezrachi, 2010; Daskalova, 2012; Nevo and van den Bergh, 2017). A study commissioned by DG Competition on concentration in food markets revealed that beyond a certain level, the presence of private labels is associated with restricted product variety (EY et al., p. 34). Despite the available scholarship and studies, no action has been undertaken by the Commission against the self-preferencing practices of supermarkets in the case of private labels. In this case, the issue is that although supermarkets often charge shelf fees and promotion money to the suppliers of branded goods that they carry, retailers' own brands are exempt from such fees. The same practice of self-preferencing was at the core of the decision in the Google Shopping case (Case AT.39740). The doctrine, which might be considered courageous in view of the established jurisprudence, has not been tested in the supermarket sector.

Another example concerns the attitude of the Commission on matters of fairness and distributive justice, especially with respect to the division of 'rents' between trading partners. The Commission has been reluctant to intervene in such cases in the food supply chain on ground that disputes about UTPs are fundamentally about the bargain struck by individual partners. At the same time, the Commission has launched several investigations with respect to breaches of FRAND (fair, reasonable and non-discriminatory) commitments 
in the context of licensing for Standard Essential Patents. It has also intervened in a number of cases involving exploitative terms of contract (European Commission, 2007a regarding Qualcomm; Case COMP/38.636-Rambus; European Commission, 2009 regarding IPCom; Case AT.39985 - Motorola; Case AT.39939 - Samsung). Notably, in these cases, the parties were not necessarily unequal in terms of bargaining power. ${ }^{43}$ The matter was deemed so important that in 2017 the Commission published Guidelines on the issue of calculating a FRAND rate (European Commission, 2017b). The most recent development has been the Commission's push for legislation on unfair platform-to-business trading practices, which resulted in the Regulation on promoting fairness and transparency for business usesrs of online intermediation services (Regulation 2019/1150). ${ }^{44}$ Claims related to exploitation of power imbalances and UTPs in the food sector have not engendered the same type or response. As the preceding paragraphs reveal, even if there has been doctrinal uncertainty about buyer power or unfair trading practices and the scope of EU competition law, there has also been sufficient scope for testing the limits of the law.

Hasty enforcement in the absence of evidence can be damaging to the market, to stakeholders and to the regulator's reputation. At the same time, failure to act can also be damaging. In a 2017 speech, Director-General for Competition at the European Commission Mr. Johannes Laitenberger seems to agree with this idea when he noted that not prosecuting sends signals to incumbents and present and prospective market players (Laitenberger, 2017). In his words 'one must be as concerned about under-enforcement as about over-enforcement' (Laitenberger, 2017). Although these are the words of the Directorate General, this has not been the attitude of DG Competition in the food sector. The European Commission has chosen to thread carefully, gather evidence, and err on the side of non-enforcement. The result, as argued above, has been that the focus of the debate has shifted - from competition law enforcement to 'other tools' such as exemptions from competition law for Annex I producers and sector-specific regulation on unfair trading practices. The sum of these regulatory responses and the ensuing complications and costs for consumers and taxpayers invites one to consider whether a measured intervention with the tools of EU competition law would have been a simpler, more efficient solution to the problem of UTPs.

${ }^{43}$ In the Huawei case, the Court of Justice of the EU observed that the parties 'have equivalent bargaining power.' (CJEU judgment of 16 July 2015, Case C-170/13 Huawei Technologies Co. Ltd v. ZTE Corp, ECLI:EU:C:2015:477, para. 37).

44 Notably, however, this is not an initiative of DG Competition. The initiators are DG CONNECT (the DG responsible for Communications Networks, Content and Technology) and DG GROW (the DG responsible for Internal Market, Industry, Entrepreneurship and SMEs), as can be verified from the Inception Impact Assessment. 


\section{Broader implications: the future of competition law, smart regulation, and the internal market}

The story of national response to UTPs in the agri-food supply chain in the EU prompts reflection on the broader implications of the choices made by the European Commission. It seems that in its decision to play a less active role, the European Commission, and DG Competition in particular, relied on assumptions about the possibilities to solve the problem of UTP by means of other laws, enacted at the national level. It has effectively achieved the goal of shifting the debate to these other areas. However, in doing so, it has arguably set some important forces in motion with questionable results.

\section{The role of other laws}

It is frequently suggested that policy problems which concern noncompetition issues, e.g. fairness or distributive justice, are best addressed via other areas of law and regulation, but not with the tools of competition law. This approach seeks to keep the scope of competition law narrow and the outcome of competition law proceedings - predictable. With Directive 2019/633, the EU Commission has once again shown a preference for 'other laws' instead of competition law. In view of the experience with legislation enacted to address UTPs, such a strict division of labour between competition law and other laws seems counterproductive. Policy problems are intertwined. As for market actors, they have to take the entire legal framework into account when organising their operations, and this includes all legal norms, be they public or private, national or European. In order to achieve the goals of smart regulation, it is important to consider whether the mix of instruments is in alignment, and to avoid sending mixed signals to market participants (Gunningham and Grabosky, 1998).

An important consequence of choosing for solutions via 'other laws' is the impact on the project of EU competition law itself. The trend of adopting diverging competition rules (or rules which could have an impact on competition) in order to regulate unfair business-to-business practices at the national level stands in stark contrast with the modernization agenda of EU competition law and with the broader goals of harmonizing trading rules within the EU. One of the main tasks for the competition law modernization program was to achieve decentralization while ensuring uniform application of the competition rules throughout the EU (European Commission, 1999). Arguably, the seeds for divergence were already in the modernization regulation itself - according to Article 3 (2) of Regulation 1/2003, 'Member States shall not under this Regulation 
be precluded from adopting and applying on their territory stricter national laws which prohibit or sanction unilateral conduct engaged in by undertakings.' Thus, while strict uniformity is required for enforcing Article 101 TFEU or national equivalents thereof, legislative divergences from the European norms on unilateral conduct are permitted. As shown in Table 1 of this article, Member States have chosen to make use of this derogation. Counterintuitively, given the modernization agenda, the European Commission has welcomed these national initiatives (European Commission, 2016a). While the Court has interpreted Regulation $1 / 2003$ in such a way as to privilege a harmonized version of what competition law is about in the EU, ${ }^{45}$ the legislative developments described encourage divergences with respect to Article 102 TFEU and possibly, indirectly, with respect to Article 101 TFEU as well. Divergence has thus become the new normal with respect to unilateral conduct rules, which means that although the scope of EU competition law has not been distorted by adding UTP concerns, EU competition law as a field has become narrower and perhaps a bit less relevant to policymakers than before.

\section{The integration imperative}

The EU competition law modernization goals aside, the Commission's tolerance for national legislation on UTPs may also be questioned from the perspective of EU integration. The EU Treaties are meant to create a level playing field by means of strict internal market rules (prohibiting states to take measures which directly or indirectly may put in place barriers to crossborder trade in goods, services, and capital, among others) ${ }^{46}$ and by means of competition law and state aid rules (the former prohibiting private parties from partitioning the internal market, the latter ensuring state resources are not used to distort the market). ${ }^{47}$

The EU has also made a lot of effort to promote harmonization in more difficult terrains - namely, by stimulating harmonization of private law, and especially of contract law, in Europe. Historically, there have been efforts to harmonize private law such as the Draft Common Frame of Reference initiative, the Principles of European Contract Law initiative and the Common

\footnotetext{
45 For instance, the Court's decision in C-375/09 Tele2 Polska (judgement of 3 May 2011, ECLI:EU:C:2011:270).

46 These provisions, so-called free movement provisions, are found in Article 28 TFEU (goods), Article 45 TFEU (workers), Article 49 TFEU (freedom of establishment), Article 56 TFEU (services), Article 63 TFEU (capital).

47 The relevant provisions are Articles 101-106 TFEU on competition and 107-109 TFEU on state aid.
} 
European Sales Law proposal (see also European Commission, 2010a). The internal market provides an important justification for such initiatives: it has been suggested that uncertainty about foreign contract law constituted an important barrier to cross-border trade within the EU (The Gallup Organization Hungary, 2011). Such uncertainties are undoubtedly augmented given the adoption of a variety of new laws and initiatives aiming at improving relations in the food supply chain. According to the researchers carrying out a mapping of the stricter laws on unilateral conduct per Member State, the legislative developments have resulted in a 'conundrum of public and private regulatory initiatives, which [...] forms a unique mix for each Member State of the European Union.' (College of Europe et al., 2014, p. 21). Although the laws may help solve the problem of UTPs, they do complicate the legal framework applicable in cross-border trading.

\section{Conclusion}

More than two decades ago, Professor Frederik Scherer wrote the following about the US agricultural policy: '...farming in the United States (and Europe too) has experienced a seemingly unending series of problems that have precipitated massive governmental interventions. These problems can be grouped under four main headings: unstable prices, an historical tendency toward poverty, wide swings in the financial fortunes of farm enterprises, and new problems introduced by the government in its attempts to solve the first three problems.' (Scherer, 1997, p. 17). These words ring true for the EU of today. Regulating agricultural markets is a difficult task. There is a lot at hand that complicates the seemingly simple goal of sustaining an adequate standard of living for the farming community while ensuring sufficient supplies for consumers: the unpredictability of nature, all the more challenging due to climate change, the threat of pests and diseases, economic factors such as global price trends and fashions in food and nutrition, the perishability of products, the availability of substitutes, the possibilities for export, and the availability of imports. In recent years, falling prices for agricultural products, increased globalization, climate change and speculation in commodities have put pressure on the margins of farmers and other food suppliers (European Commission, 2014b). ${ }^{48}$ Rising input costs, especially for labor and energy

48 This document discusses milk price developments in light of climate, animal feed prices, energy costs, global consumption and production trends, trends for using land (eg. for biogas production), etc. 
have also played a role (European Competition Network Subgroup on Food, 2012). ${ }^{49}$

Amid these many forces (of nature and markets), the superior bargaining power of contracting partners seems to be but one of many farmer woes. Nonetheless, as has been argued in this article, power imbalances play an important role in shaping agricultural markets. Failing to address concentration on purchasing markets and the practices it enables frustrates not only farmer expectations, but also the regulator's ability to intervene and correct other challenges in the sector (unpredictability of supply, unpredictability of demand, fickle global markets) or to achieve other goals such as environmental protection, rural development and social cohesion.

UTP legislation, including the latest development - Directive 2019/633 on unfair trading practices in business-to-business relationships in the agricultural and food supply chain - may be a step in the right direction, but generally does not offer a comprehensive solution. Importantly, UTP laws do not address the issue of concentration on purchasing markets, concerns about unfair prices, or possible structural bottlenecks. Vigorous enforcement may have a deterrent effect, but it is no substitute for competition law tools such as sector inquiries, investigations into excessive pricing, the possibility to impose structural remedies such as divestiture and compulsory dealing, and merger control. This is where competition law could play a role - by ensuring deconcentrated markets in which both buyers and sellers have a choice of contracting partners (Zimmer, 2012).

This article has taken a critical look at the consequences of delegating the policy problem of UTPs to 'other laws' - unfair trading laws, stricter competition rules, subsidy schemes and sector-specific competition regimes such as the CAP. It has argued that these regulatory interventions fit a number of scenarios of counterproductive regulation described by Grabosky (1995). The experiences discussed reveal the limits of national regulatory measures in an integrated market and the need for coordination of implementation and enforcement across jurisdictions - in order to avoid forum shopping and de facto circumvention. Differences in terms of quality of implementation and in terms of intensity and quality of enforcement can replicate the counterproductive effects described earlier in this article.

Making a market may in the first place be about abolishing restrictions to trade, and only in a second place - about correcting externalities and achieving

49 According to a European Competition Network Report, 'the biggest cost elements of final food prices are energy and in particular labour, which, on average, accounts for 70-75\% of consumer food pricing in developed economies (European Competition Network Subgroup on Food, 2012, p. 13, 17). The report also draws attention to commodity speculation as well as the role of powerful buyers (p. 17). 
socially palatable results. In theory, it may be logical to keep market-making and market-correcting apart: competition law keeps markets open, and other instruments make sure that other goals can be achieved. In practice, as this article has attempted to show, market-making and market-correcting are interwoven, and failure to fine-tune the division of labour between different legal disciplines, policy areas and levels of regulation may be costly. Instead of smart regulation, the result may well be counterproductive regulation. Perhaps keeping EU competition law away from thorny issues of fairness and distributive justice was a prudent choice for the EU competition enforcers. However, one can also think of it as a missed opportunity for EU competition law to safeguard consumer welfare, promote a culture of competition (not protection), and not least of all - create a level playing field on an integrated market.

\section{Literature}

ABC News. (2014). Government subsidies received by farmers, 13 Feb 2014. Retrieved from: https://www.abc.net.au/news/2014-02-13/government-subsidies-received-byfarmers $/ 5255578$ ? $\mathrm{nw}=0(05.07 .2020)$.

ACCC. (2014). Court finds Coles engaged in unconscionable conduct and orders Coles pay $\$ 10$ million penalties. Press Release MR 320/14, 22.12.2014. Retrieved from: https:// www.acc.gov.au/media-release/court-finds-coles-engaged-in-unconscionable-conductand-orders-coles-pay-10-million-penalties' (05.07.2020).

ACCC. (2016a). ACCC won't appeal Woolworths unconscionable conduct decision. Press Release MR 245/16, 16.12.2016. Retrieved from: https://www.accc.gov.au/mediarelease/accc-won\%E2\%80\%99t-appeal-woolworths-unconscionable-conduct-decision (05.07.2020).

ACCC. (2016b). Woolworths' "Mind the Gap" scheme not unconscionable. Press Release MR 234/16, 8.12.2016. Retrieved from: https://www.accc.gov.au/media-release/ woolworths'-"mind-the-gap"-scheme-not-unconscionable (05.07.2020).

Agricultural Markets Task Force. (2016). Enhancing the Position of Farmers in the Supply Chain' (Report), Annex E: Contribution by Mr. Sarmir. Brussels, Belgium.

Alons, G. and Zwaan, P. (2016). New Wine in Different Bottles: Negotiating and Selling the CAP post-2013 Reform. Sociologia Ruralis, 56 (3), 349-370, https://doi.org/10.1111/ soru. 12088

Australian Competition and Consumer Commission. (2016). ACCC won't appeal Woolworths unconscionable conduct decision. Press Release, 16.12.2016.

Baltic International Center for Economic Policy Studies (BICEPS). (2006). Competition in Baltic Grocery Retail Markets. Retrieved from: http://www.biceps.org/assets/docs/ izpetes-zinojumi/Competition_in_Baltic_Grocery_Retail_Markets.pdf. (05.07.2020). 
Bundeskartellamt (German Competition Authority). (2018). Federal Court of Justice confirms key points of Bundeskartellamt's landmark decision concerning unfair trading practices. Press Release, 29.01.2018.

Bureau, J-C. (2012). Where Is the Common Agricultural Policy Heading? 6 Forum Intereconomics, 47(6), 316-321, https://doi.org/10.1007/s10272-012-0435-6

Cafaggi, F. and Iamicelli, P. (2018). Unfair Trading Practices in the Business-to-Business Retail Supply Chain: An overview on EU Member States legislation and enforcement mechanisms. JRC Technical Reports JRC112654. Luxembourg: Publications Office of the European Union.

Cafaggi, F. and Iamicelli, P. (2019). Unfair Trading Practices in Food Supply Chains. Regulatory Responses and Institutional Alternatives in the Light of the New EU Directive. SSRN Electronic Journal, 1-26.

Chauve, P. (2019). Retail alliances under EU competition law. Presentation delivered on 5.11.2019 in Brussels, Belgium. Retrieved from: https:/ec.europa.eu/jrc/sites/jrcsh/files/ ra_4_1_chauve_ra_under_eu_competition_law.pdf (05.07.2020).

Colen, L., Bouamra-Mechemache, Z., Daskalova, V. and Nes, K. (2020). Retail alliances in the agricultural and food supply chain. JRC Technical Reports JRC120271. Luxembourg: Publications Office of the European Union.

College of Europe, European University Institute, and Center for European Policy Studies. (2014). Study on the Legal Framework Covering Business-to-Business Unfair Trading Practices in the Retail Supply Chain. (Report prepared for the European Commission, DG MARKT/2012/049/E, 2014). European Union Publications, https:// doi.org/10.2780/91447

Dam, K.W. (1967). The European Common Market in Agriculture. Columbia Law Review 67(2), 209.

Daskalova, V. (2012). Private labels (Own Brands) in the Grocery Sector: Competition Concerns and Treatment in EU Competition Law. TILEC Discussion Paper 2012-02.

Daskalova, V. (2019). The New Directive on Unfair Trading Practices in Food and EU Competition Law: Complementary or Divergent Normative Frameworks? Journal of Competition Law and Practice, 10(5), 281-296.

de Quesada, C.E. (2017). Explotación de la Dependencia Económica en las Redes de Distribución Pamplona, Spain: Thomson Reuters Aranzadi.

DG Agriculture and Rural Development, Unit Farm Economics. (2017). Factsheet: The Food Supply Chain. https://ec.europa.eu/info/sites/info/files/food-farming-fisheries/ farming/documents/factsheet-food-supply-chain_march2017_en.pdf

EIM. (2009). De aard en omvang van inkoopmacht: Onderzoek naar de perceptie van leveranciers (2009) Report prepared for the Dutch Ministry of Economic Affairs.

European Commission, DG Agriculture. (2020). The Milk Package. Retrieved from: https://ec.europa.eu/agriculture/milk/milk-package_en (05.07.2020).

European Commission. (1999). White Paper on Modernization of the Rules Implementing Articles 85 and 86 of the EC Treaty. Brussels, Belgium.

European Commission. (2007a). Antitrust: Commission initiates formal proceedings against Qualcomm. Memo/07/389.

European Commission. (2007b). Communication to the Council, the European Parliament, the European Social and Economic Committee and the Committee of the Regions: Overcoming the stigma of business failure - for a second chance policy. Brussels, Belgium. COM(2007) 584 final. 
European Commission. (2009). Antitrust: Commission welcomes IPCom's public FRAND declaration. Memo/09/549.

European Commission. (2010a). Green Paper from the Commission of 1 July 2010 on policy options for progress towards a European Contract Law for consumers and businesses. COM(2010) 348 final. Brussels, Belgium.

European Commission. (2010b). The Interface between EU Competition Policy and the Common Agriculture Policy (CAP): Competition Rules Applicable to Cooperation Agreements between Farmers in the Dairy Sector (Working Paper). Brussels, Belgium.

European Commission. (2013a). CAP Reform - an explanation of the main elements (Memo). Brussels, Belgium, 26 June 2013. Retrieved from: http://europa.eu/rapid/pressrelease_MEMO-13-621_en.htm (05.07.2020).

European Commission. (2013b). Green Paper on Unfair Trading Practices in the Businessto-Business Food and Non-Food Supply Chain in Europe. COM/2013/037 final. Brussels, Belgium.

European Commission. (2014a). Communication from the Commission to the European Parliament, the Council, the European Economic and Social Committee and the Committee of the Regions. Tackling unfair trading practices in the business-to-business food supply chain. COM(2014) 472 final.

European Commission. (2014b). Evolution of the market situation for milk and milk products. Staff Working Document Accompanying the Report from the Commission to the European Parliament and the Council Development of the dairy market situation and the operation of the "Milk Package" provisions. SWD/2014/0187 final.

European Commission. (2015). Commission Notice: Guidelines on the application of the specific rules set out in Articles 169, 170 and 171 of the CMO Regulation for the olive oil, beef and veal and arable crops sectors. OJ C/431, 1.

European Commission. (2016a). Report from the Commission to the European Parliament and the Council on unfair business-to-business trading practices in the food supply chain. $\operatorname{COM(2016)} 32$ final. Brussels, Belgium.

European Commission. (2016b). Evolution of compulsory contracts, Producer Organisations and the market situation for milk and milk products. Working Document Accompanying Report from the Commission to the European Parliament and the Council: Development of the dairy market situation and the operation of the "Milk Package". COM(2016) 724 final \{SWD(2016) 367 final\}. Brussels, Belgium.

European Commission. (2016c). Guidance on the Implementation/Application of Directive 2005/29/EC on Unfair Commercial Practices. Brussels, Belgium. SWD (2016) 163 final.

European Commission. (2017a). Antitrust: Commission fines three companies $€ 68$ million for car battery recycling cartel. Press release, 8.02.2017.

European Commission. (2017b). Communication from the Commission to the European Parliament, the Council and the European Economic and Social Committee. Setting out the EU approach to Standard Essential Patents. COM(2017) 712 final. Brussels, Belgium.

European Commission. (2017c). Dual quality food products: Commission guides Member States to better tackle unfair practices. Press release, 26.09.2017, http://europa.eu/rapid/ press-release_IP-17-3403_en.htm (05.07.2020).

European Commission. (2019). 'Common Agricultural Policy: Key graphs \& figures' (July 2019) https://ec.europa.eu/info/sites/info/files/food-farming-fisheries/farming/ documents/cap-expenditure-graph1_en.pdf (05.07.2020). 
European Commission. (2019a). Common Agricultural Policy: Key graphs \& figures. (July 2019). Retrieved from: https://ec.europa.eu/info/sites/info/files/food-farming-fisheries/ farming/documents/cap-expenditure-graph1_en.pdf

European Commission. (2020). Communication from the Commission to the European Parliament, the Council, the European Economic and Social Committee and the Committee of the Regions: A Farm to Fork Strategy for a fair, healthy and environmentally-friendly food system. Brussels, Belgium. COM(2020) 381 final.

European Commission. (No date, a). The common agricultural policy at a glance. Retrieved from https://ec.europa.eu/agriculture/cap-overview_en (05.07.2020).

European Commission. (No date, b). Young Farmers. Retrieved from https://ec.europa. eu/info/food-farming-fisheries/key-policies/common-agricultural-policy/income-support/ young-farmers_en (05.07.2020).

European Competition, Network Subgroup on Food. (2012). Report on competition law enforcement and market monitoring activities by European competition authorities in the food sector. Retrieved from: https://ec.europa.eu/competition/ecn/food_report_ en.pdf (05.07.2020).

European Parliament. (2016a). Resolution of 19 January 2016 on the Annual report on EU Competition Policy (2015/2140(INI)).

European Parliament. (2016b). Resolution of 7 June 2016 on unfair trading practices in the food supply chain (2015/2065(INI)) [2018] OJ C 086/05.

European Supply Chain Initiative (No date). Retrieved from: https://www. supplychaininitiative.eu/ (05.07.2020).

EY, Arcadia International and Cambridge Econometrics Ltd. (2014). The economic impact of modern retail on choice and innovation in the EU food sector (Report prepared for the European Commission). Luxembourg: Publications Office of the European Union, https://doi.org/10.2763/77405.

Ezrachi, A. (2010). Unchallenged Market Power? The Tale of Supermarkets, Private Labels and Competition Law. World Competition, 33(2), 13.

Ezrachi, A. and Bernitz, U. (eds). (2009). Private Labels, Brands and Competition Policy. The Changing Landscape of Retail Competition. Oxford: Oxford University Press.

Food Drink Europe. (2011). Market share of the top three retailers in selected EU countries. Brussels, Belgium. Retrieved from: http:/www.fooddrinkeurope.eu/uploads/ publications_documents/Final_Data_Trends_30.4.2012.pdf (05.07.2020).

French Ministry of Agriculture and Food website. \#EGalim: ce que contient la loi Agriculture et Alimentation. 11.02.2019. Retrieved from: https://agriculture.gouv.fr/ egalim-ce-que-contient-la-loi-agriculture-et-alimentation (05.07.2020).

Gale, F.H. (1993). Why did the number of young farmers decline? American Journal of Agricultural Economics 75, 138-146.

Gasson, R. (1986). Part time farming: strategy for survival? Sociologia Ruralis 24, 364-359.

Gorecki, P. (2009). A Code of Practice for Grocery Goods Undertakings and An Ombudsman: How to Do a Lot of Harm by Trying to Do a Little Good. The Economic and Social Review 40 (4), 461-488.

Grabosky, P. N. (1995). Counterproductive Regulation. International Journal of the Sociology of Law, 23 (4), 347-369, https://doi.org/10.1016/S0194-6595(05)80003-6

Gunningham, N. and Grabosky, P. (1998). Smart Regulation: Designing Environmental Policy. New York, USA: Oxford University Press. 
Hodonova, Z. and Oleksik, R. (2010). Slovakia's Unfair Terms in Business Contracts Between Resellers and Suppliers of Foodstuffs. Retrieved from: http://www.kinstellar. com/insights/detail/100/slovakias-unfair-terms-in-business-contracts-between-resellersand-suppliers-of-foodstuffs (05.07.2020).

Hogan, P. (2017). Speech at EU Agricultural Outlook Conference 2017 at EU Agricultural Outlook Conference 2017, 18.12.2017.

Kirkwood, J. (2014). Collusion to Control a Powerful Customer: Amazon, E-Books, and Antitrust Policy. University of Miami Law Review 69(1), 1-64.

Laitenberger, J. (Director-General for Competition, European Commission). (2017). Accuracy and administrability go hand in hand. Speech delivered at the CRA Conference on 12.12.2017. Brussels, Belgium 12 December 2017. Retrieved from: http://ec.europa. eu/competition/speeches/text/sp2017_24_en.pdf (05.07.2020).

Nevo, H. and van den Bergh, R. (2017). Private Labels: Challenges for Competition Law and Economics. World Competition, 40(2), 271-298.

Nordic Competition Authorities. (2005). Joint Report: Nordic Food Markets - a taste for competition. Retrieved from: https://www.kkv.fi/globalassets/kkv-suomi/julkaisut/ pm-yhteisraportit/nordic_food_markets.pdf (05.07.2020).

OECD. (2008). Roundtable on Monopsony and Buyer Power. DAF/COMP(2008)38.

OECD. (2010). Roundtable on Competition, State Aids and Subsidies. DAF/COMP/ $\mathrm{GF}(2010) 5$.

PMR Newsletter. (2011). Slovakia's retail law repealed (18.01.2011) (article no longer available online).

Scheelings, R. and Wright, J.D. (2006). 'Sui Generis'?: An Antitrust Analysis of Buyer Power in the United States and European Union. Akron Law Review, 39 (1), 207-243.

Scherer, F.M. (1997). Industry Structure, Strategy, and Public Policy. Pearson.

SEO Economisch Onderzoek. (2013). Oneerlijke handelspraktijken: voldoet bestaande (zelf)regulering? Amsterdam, the Netherlands. Retrieved from: http://www.seo.nl/ uploads/media/2013-04_Oneerlijke_handelspraktijken.pdf (05.07.2020).

Smith, R. and Castellnou, M. (2015). SMEs \& Competition Law. Qualitative Research Report. BDRC Continental.

Spanish Competition Authority. (2010). Report on Competition and the Agrifood Sector' (Informe sobre Compencia y Sector Agroalimentario) https:/www.cnmc.es/sites/default/ files/1185937_5.pdf (05.07.2020).

The Gallup Organization Hungary. (2011). European contract law in business-to-business transactions: Analytical Report (Report prepared for DG JUSTICE of the European Commission). Retrieved from: http://ec.europa.eu/commfrontoffice/publicopinion/flash/ fl_320_en.pdf (05.07.2020).

TISCO. (2012). Eerlijk, scherp en betrouwbaar. Een interactieve verkenning naar ijkpunten voor eerlijk zakendoen en effectieve conflictoplossing. Retrieved from: https://www. parlementairemonitor.nl/9353000/1/j9vvij5epmj1ey0/vix1ordxlvyi (05.07.2020).

UK Competition Commission. (2000). Supermarkets: A report on the supply of groceries from multiple stores in the United Kingdom. London, UK: Competition Commission. Retrieved from: http://webarchive.nationalarchives.gov.uk/+/http://www.competitioncommission.org.uk//rep_pub/reports/2000/446super.htm (05.07.2020).

UK Competition Commission. (2008). Groceries market investigation. London, UK: Competition Commission. Retrieved from: http://webarchive.nationalarchives.gov. uk/20140402194746/http://www.competition-commission.org.uk/our-work/directory-of- 
all-inquiries/groceries-market-investigation-and-remittal/final-report-and-appendicesglossary-inquiry (05.07.2020).

UK Groceries Code Adjudicator (2020). Guidance: Code Provisions and Related GCA Action. (24.06.2020). Retrieved from: https://www.gov.uk/government/publications/codeprovisions-and-related-gca-action/code-provisions-and-related-gca-action (05.07.2020).

Valetti, T. (2018). Regulating Unfair Trading Practices: Economic impact on farmers, processors, retailers and consumers. Presentation delivered for the European Parliament on 24.09.2018. Retrieved from: https://www.europarl.europa.eu/cmsdata/153622/ Valletti-COMAGRI-24092018_v4.2_CLEAN.pdf (05.07.2020).

Van Herck, K. (2009). A comparative analysis of rural labour markets. SCARLED Project Deliverable 7.4. Retrieved from: http://www.scarled.eu/uploads/media/SCARLED_ D7.4.pdf (05.07.2020).

Wakui, M. and Cheng, T. (2015). Regulating abuse of superior bargaining position under the Japanese competition law: an anomaly or a necessity?. Journal of Antitrust Enforcement (0), 1-32.

Zimmer, D. (2012). The Basic Goal of Competition Law: To Protect the Opposite Side of the Market. In Zimmer, D. (ed). The Goals of Competition Law. Edward Elgar, 2012. 